\title{
Promoting Sustainable Public Finances in the European Union The Role of Fiscal Rules and Government Efficiency
}

Bergman, Michael; Hutchison, Michael M.; Hougaard Jensen, Svend E.

Document Version

Accepted author manuscript

Published in:

European Journal of Political Economy

DOI:

10.1016/j.ejpoleco.2016.04.005

Publication date:

2016

License

CC BY-NC-ND

Citation for published version (APA):

Bergman, M., Hutchison, M. M., \& Hougaard Jensen, S. E. (2016). Promoting Sustainable Public Finances in the European Union: The Role of Fiscal Rules and Government Efficiency. European Journal of Political Economy, 44, 1-19. https://doi.org/10.1016/j.ejpoleco.2016.04.005

Link to publication in CBS Research Portal

\section{General rights}

Copyright and moral rights for the publications made accessible in the public portal are retained by the authors and/or other copyright owners and it is a condition of accessing publications that users recognise and abide by the legal requirements associated with these rights.

Take down policy

If you believe that this document breaches copyright please contact us (research.lib@cbs.dk) providing details, and we will remove access to the work immediately and investigate your claim. 


\title{
Promoting Sustainable Public Finances in the European Union: The Role of Fiscal Rules and Government Efficiency
}

\author{
Michael Bergman, Michael M. Hutchison, and Svend E. Hougaard Jensen \\ Journal article (Post print version)
}

\begin{abstract}
Cite: Promoting Sustainable Public Finances in the European Union : The Role of Fiscal Rules and Government Efficienc. / Bergman, Michael; Hutchison, Michael M.; Hougaard Jensen, Svend E. In: European Journal of Political Economy, Vol. 44, 09.2016, p. 1-19.
\end{abstract}

DOl: http://dx.doi.org/10.1016/j.ejpoleco.2016.04.005

Uploaded to Research@CBS: September 2016

(C) 2016. This manuscript version is made available under the CC-BY-NC-ND 4.0 license http://creativecommons.org/licenses/by-nc-nd/4.0/ 


\title{
Promoting Sustainable Public Finances in the European Union: The Role of Fiscal Rules and Government Efficiency
}

\author{
U. Michael Bergman \\ Department of Economics, University of Copenhagen \\ Øster Farimagsgade 5, Building 26, DK-1353 Copenhagen K, Denmark \\ Michael.Bergman@econ.ku.dk \\ Michael M. Hutchison \\ Department of Economics, University of California, Santa Cruz \\ Santa Cruz, CA 95064 USA \\ hutch@ucsc.edu \\ Svend E. Hougaard Jensen \\ Department of Economics, Copenhagen Business School \\ Porcelaenshaven 16A, 2000 Frederiksberg C, Denmark \\ shj.eco@cbs.dk
}

July 2015

(Revised March 2016)

\begin{abstract}
New indices of fiscal rule strength are constructed and, using a dynamic panel econometric model for 27 EU countries over the period 1990-2012, we assess whether national fiscal rules alone help to promote sustainable public finances in the EU or whether they must be supported by good governance in order to be effective. We find that fiscal rules are effective in reducing structural primary deficits at all levels of government efficiency. However, the effect is smaller as government efficiency increases, indicating that fiscal rules and government efficiency are institutional substitutes in terms of promoting fiscal sustainability. We also find that balanced budget rules are the most effective form of fiscal rules. Multiple fiscal rules are found to enhance fiscal solvency. Other institutional features that enhance the effectiveness of fiscal rules are transparency of policies and commitment to implementation of fiscal programs. Supranational rules, however, do not affect the effectiveness of national fiscal rules in reducing the deficit bias. Our results are robust to alternative estimation methods and endogeneity assumptions.
\end{abstract}

Keywords: Deficit bias; Fiscal sustainability; Fiscal rules; Government efficiency; European Union. JEL codes: E62, F36, F44, G14, H63 


\section{INTRODUCTION}

The fiscal crisis in the European Union (EU) has spurred a renewed emphasis on designing and implementing stronger fiscal rules and institutions. The best known fiscal rules in Europe, as embodied in the EU's Stability and Growth Pact (SGP), did not adequately promote sustainable public finances in the region prior to the Global Financial Crisis (Hughes Hallett and Jensen, 2012; Schuknecht et al., 2011). In an attempt to address this problem, the Fiscal Compact, part of the March 2012 Treaty on Stability, Coordination and Governance (TSCG), introduces new rules on public finances which signatories to the Treaty agreed to implement into their national legislation.

It is not obvious, however, whether legislated national rules in the EU are likely to impose greater fiscal discipline than the SGP supranational rules. Nonetheless, several European countries have apparently found national fiscal rules to be helpful in achieving greater budgetary discipline. ${ }^{1}$ And previous research finds evidence that sustainable public finances in Europe may be associated with strong fiscal rules (Debrun et al. 2008; Wierts, 2008; Afonso and Hauptmeier, 2009; Dahan and Strawczynski, 2010; Holm-Hadulla et al., 2012; Nerlich and Reuter, 2013; Foremny, 2014; Afonso and Guimarães, 2014). Moreover, strong fiscal rules are associated with lower risk premia on national debt (Iara and Wolff, 2014) and output stabilization of discretionary fiscal policy (Sacchi and Salotti, 2015). ${ }^{2}$

This literature, however, has not fully addressed the interaction of national fiscal rules with broader government institutional arrangements. Good governance and the efficiency of government institutions have been shown to be helpful in promoting sustainable public finances in various contexts (Albuquerque, 2011; Bergman and Hutchison, 2015; Calderón et al., 2012; Frankel et al., 2013; Hallerberg et al., 2007; von Hagen and Harden, 1995). This is

\footnotetext{
${ }^{1}$ For example, Sweden, Finland and the Netherlands all realized improvements in their fiscal situations after adopting rules that limit spending (Ayuso-i-Casals, 2012).

${ }^{2}$ Iara and Wolff (2014) find that stronger fiscal rules in euro area members reduce sovereign risk premia during times of market stress. Using the EC data set of rules-based fiscal governance in EU member states, they estimate a model of sovereign spreads that are determined by the probability of default in interaction with the level of risk aversion. They find that the legal base of the rules and their enforcement mechanisms are the most important dimensions of rules-based fiscal governance. Sacchi and Salotti (2015) study the relationship between discretionary fiscal policy and macroeconomic stability in 21 OECD countries over the 1985-2012 period. They find that strict fiscal rules induce discretionary policy to become output-stabilizing rather than destabilizing. They find that this result can be more easily achieved by rules on balanced budgets, rather than on expenditures, revenues, or debt.
} 
an interesting question for the EU also as indicators of government efficiency vary widely across the member states.

In addition, we investigate which specific types of fiscal rules (balanced budget rules, debt rules, expenditure rules or revenue rules) are most effective in promoting fiscal solvency. This analysis directly relates to the debate in Europe over the optimal design of fiscal rules and, in particular, whether the constraints embodied in the Fiscal Compact are likely to be effective.

The main contributions of our study are threefold. First, we construct a new aggregate index of fiscal rule strength and four new sub-aggregate indices of the strength of specific types of fiscal constraints (expenditure rules, balanced budget rules, revenue rules and debt rules). These five new refined measures of the strength of fiscal rules, varying across countries and over time, are based on the specific characteristics of various types of fiscal constraints using the IMF FAD data base (Schaechter et al., 2012).

Second, we combine the fiscal rule and governance literatures to determine whether national fiscal rules alone help to promote sustainable public finances in Europe or whether they must be supported by good governance in order to be effective. For this evaluation we employ a dynamic panel econometric model for 27 EU countries over the period 1990-2012. The interaction of fiscal rules with governance is assessed using the World Bank "efficiency of government bureaucracy" index. ${ }^{3}$ This index is part of the World Bank "Worldwide Governance Indicators, 2013 Update" (WGI) project research dataset. This indicator measures perceptions of the efficiency of public services, the quality of the civil service and the degree of its independence from political pressures, the quality of policy formulation and implementation, and the credibility of the government's commitment to such policies. We also consider alternative measures of institutional quality, including policy transparency and commitment to fiscal program implementation.

Third, we investigate which specific type of fiscal rules - balance budget, expenditure, revenue or debt rules — are most effective in promoting fiscal solvency. In all cases, we

\footnotetext{
${ }^{3}$ Charron et al. (2010) find in their comparison of alternative measures of quality of government that the World Bank data are both empirically and conceptually superior and provide the best measurement for reliable and meaningful comparisons of quality of government in the EU.
} 
focus on the interaction of fiscal rules and good governance in promoting sustainable fiscal finances in Europe.

The road map of the paper is as follows. Section 2 presents a brief review of the literature that provides a theoretical motivation for our empirical hypotheses. Section 3 presents the empirical model and methodology. Section 4 discusses the data and construction of our fiscal strength indices. Section 5 presents the empirical results and consists of summary statistics, tests of the baseline model (fiscal rule strength and fiscal solvency, interacted with government efficiency) and tests of the effectiveness of specific types of rules. Section 6 presents extensions and robustness tests. Section 7 concludes.

\section{Fiscal Rules: Theory, Literature And Model}

Fiscal rules are generally legislative agreements intended to mitigate "deficit bias" and promote fiscal discipline by "tying the hands" of policy makers in order to constrain decisions about spending and revenue programs. The main causes of deficit bias cited in the literature are governments" "short-sightedness" and the "common pool" problem, although the "time inconsistency" problem and many other political and economic factors have been suggested. Short-sightedness may be attributable to several reasons, including governments running excessive deficits in anticipation of being replaced by another political party in future (Persson and Svensson, 1989; Alesina and Tabellini, 1990). Deficit bias may also arise because spending measures tend to be targeted at specific interest groups but financed by general taxation. This creates the potential for free-riding problems emphasized by the common pool explanation for deficit bias (Velasco, 2000; Weingast et al., 1981). Time inconsistency may create a problem for governments to commit to fiscal disciple, leading to excessive deficits, as these commitments may not be credible in the face of the incentive to simulate short-run aggregate demand (Persson and Persson, 1987; Persson et al., 2006).

In the literature, a myriad of solutions have been proposed to reduce deficit bias, including fiscal rules. Debrun et al. (2008), for example, identifies four broad categories of solutions to the deficit bias problem: (1) fiscal policy-makers may be held more accountable for their actions (Corbacho and Schwartz, 2007); (2) improved budgetary procedures that govern the preparation, approval and implementation of annual budget laws (von Hagen and Harden, 1995); (3) delegating fiscal policy or aspects of fiscal policy to institutions that are insulated from short-term political pressures (Wyplosz, 2005); and (4) curtailing discretion of fiscal 
authorities by ex ante fiscal rules for numerical targets or ceilings for fiscal aggregates or set benchmarks for the conduct of fiscal policy (Krogstrup and Wyplosz, 2010). ${ }^{4}$

The theoretical basis for rules as a solution for deficit bias is not fully articulated, and should in principle be formulated in the context of the specific circumstances generating excessive deficits. From a theoretical perspective, rules constraining the choices of fiscal policy-makers may be a second best solution to the deficit bias problem. A more targeted approach attempting to solve the underlying political-economic source of the deficit bias would generally be an optimal policy. However, in the absence of a more fundamental solution, fiscal rules may be useful. Von Hagen and Harden (1995) and Hallerberg and von Hagen (1999) use political economy models of the deficit bias to show that fiscal restraints can be desirable and that delegation of the budget decision reduces the bias. Primo (2006) uses a distributive politics model to establish that budget ceilings reduce deficits. Beetsma and Uhlig (1999) show that fiscal rules may be welfare improving in the presence of a deficit bias, but also that some rules (such as those implied by the Stability and Growth Pact) may have the undesirable side effect of reducing productive as well as unproductive public spending (Beetsma and Debrun, 2004 and 2005).

Krogstrup and Wyplosz (2010) consider fiscal policy in the context of a domestic common pool problem combined with an international externality. This setup creates a deficit bias, and they analyze the welfare effects of imposing binding national and supra-national fiscal rules on debt/deficits. In this context, they find that a supranational deficit ceiling is welfare improving relative to a national fiscal ceiling, but both dominate the case with no rules. However, fiscal rules do not fully eliminate deficit bias unless combined with a domestic fiscal institution allowing for pre-commitment to productive public spending. The notion that strong domestic fiscal institutions, or more generally efficient government bureaucracies, combined with fiscal rules may be necessary to reduce or eliminate deficit bias is an important point. Foremny (2014) notes that there is a large variation in public finances and debt levels, even between countries with similar economic conditions and suggests that the

\footnotetext{
${ }^{4}$ Lavigne (2011) empirically investigates the role of political and institutional factors in determining why countries get into fiscal distress, why some are able to fiscally consolidate when required, and why others are unable to adjust despite an evident need to do so. For advanced countries, he finds that fiscal rules contribute to avoiding situations of fiscal distress, and fiscal performance management systems improve the odds of implementing adjustments.
} 
differences in deficit bias can be attributed to cross-country differences in political and institutional factors.

One of these institutional factors leading to excessive deficits may be inefficient government bureaucracies, while efficient governments may promote fiscal solvency (Muscatelli et al., 2012), especially when combined with fiscal rules. ${ }^{5}$ Some authors have found institutional structures are important in the effectiveness of fiscal rules. For example, Foremny (2015) finds that the effectiveness of rules depends on the constitutional structure of government. ${ }^{6}$ Iara and Wolff (2014) find that the legal basis of fiscal rules and their enforcement mechanisms are the most important dimensions of rules-based fiscal governance. As noted, Krogstrup and Wyplosz (2010) emphasize deficit ceiling combined with fiscal institutions. Muscatelli et al. (2012) argue that transparency in the decision making process helps achieve fiscal solvency.

This suggests that efficient government bureaucracies may be a necessary pre-condition for the formulation, implementation and monitoring of fiscal rules. Strong fiscal rules alone may not be enough, perhaps necessitating a critical threshold level of government efficiency, i.e. fiscal rules and government efficiency may be policy/institutional complements. On the other hand, fiscal rules and government efficiency may be policy/institutional substitutes in the sense that fiscal rules may not be necessary, or at least do not contribute much to reducing deficit bias, against an institutional background of a highly efficient government bureaucracy.

Against this, the present paper considers several hypotheses relating to fiscal rules, government efficiency and the specific-type of fiscal rules:

H1: Stronger fiscal rules, i.e. those characterized by attributes such as monitoring, enforcement and with independent agents, are associated with less deficit bias.

\footnotetext{
${ }^{5}$ In Muscatelli et al. (2012) a monetary union is modelled where fiscal discretion generates excessive debt accumulation in steady state and inefficiently delayed debt adjustment following shocks. By setting a debt target and raising the political cost of deviating from the optimal pace of debt reversal, institutional design induces fiscal policymakers to implement unbiased responses to shocks. This is partly achieved by increasing the transparency of the decision-making process.

${ }^{6}$ Foremny (2015) empirically examines how fiscal rules influence deficits of sub-national sectors across European countries. It is found that the effectiveness of fiscal rules depends on the constitutional structure. Specifically, fiscal rules decrease deficits only in unitary countries.
} 
H2: More efficient governments are associated with less deficit bias.

H3: Stronger fiscal rules are more effective in reducing deficit bias on the margin if combined with a high level of government efficiency (complementarity hypothesis).

H4: Stronger fiscal rules are less effective in reducing deficit bias on the margin if combined with a high level of government efficiency (substitutability hypothesis).

H5: Revenue rules are likely to be less effective than expenditure, balanced budget and debt rules in reducing deficit bias.

The last-mentioned hypothesis needs further clarification. Although any type of fiscal rule could in principle be effective in reducing the deficit bias - the government deficit is tied to expenditures, revenues and debt levels by a dynamic accounting identity - there may be political economy, institutional or informational/transparency reasons why one rule may dominate another in terms of effectiveness. A priori we expect revenue rules to be least effective amongst the four types of rules in reducing deficit bias. Government revenue is considerably more sensitive to the business cycle than government expenditures. For example, Girouard and André (2005) show that the average elasticity of current primary expenditures with respect to the output gap is -0.11 in the euro area, whereas the elasticity of taxes are well above unity on average and about 0.70 for social security contributions. Thus, budget offices and legislatures have less control over revenues and more control over expenditures. For this reason, it is likely that fiscal rules focusing on limiting public expenditures are more effective than rules focusing on constraining revenues.

\section{Model Specification And Methodology}

To analyze whether there is a relation between fiscal rules, government efficiency and fiscal performance we estimate the following dynamic panel regression

$$
P B C A_{i, t}=\alpha+\beta_{0} P B C A_{i, t-1}+\beta_{2} F R I_{i, t}+\beta_{3} G E_{i, t}+\beta_{4} G E_{i, t} F R I_{i, t}+X_{i, t}^{\prime} \gamma+\varepsilon_{i, t}
$$

where $P B C A_{i, t}$ is the cyclically-adjusted primary balance; $F R I_{t}$ is the numerical national fiscal rule strength index; $G E_{t}$ is the numerical degree of government efficiency index; and 
$X_{i, t}$ is a vector of control variables. ${ }^{7}$ In equation (1) we include the interaction between government efficiency and the strength of fiscal rules allowing us to address the question whether these two variables are substitutes or complements.

Our empirical investigation mainly focuses on whether stricter fiscal rules, and what types of rules, lead to better fiscal performance, and whether the effectiveness of rules is influenced by the degree of government efficiency. We discuss these variables of interest and the control variables in the next section.

The model is a dynamic panel, estimated using Blundell-Bond (1998) system GMM, where we report coefficient estimates and Windmeijer's (2005) finite-sample corrected standard errors. We also report tests of autocorrelation of both first and second order and the Hansen $\mathbf{J}$ test statistic for over-identifying restrictions (the joint validity of all instruments). If the model is well-specified we expect to reject the null of first order autocorrelation, not reject second order autocorrelation and not reject the Hansen $\mathrm{J}$ test.

A potential problem when implementing GMM methods is that the number of instruments is quadratic in $T$. This is also a potential problem in our panel. Roodman (2009b) discusses many of the potential pitfalls of instrument proliferation and its consequences, including over fitting of endogenous variables, bias in estimates and the weakening of Sargan tests. These issues have not been fully analyzed in the literature and there exists very little guidance on how to handle this problem in GMM estimation of dynamic panel data models, see the discussions in Hall and Peixe (2003), Roodman (2009b) and Bontempi and Mammi (2012). Roodman (2009b) suggests either that the number of instruments is limited to certain lags or a method of collapsing the instruments by having separate moments for each lag instead of for each lag and time period. We will use the latter approach in our empirical application. ${ }^{8}$

The GMM estimator with fixed effects helps with potential omitted variable bias. In particular, there may be time invariant differences in preferences for sustainable public finances across European countries so that countries with a preference for more stable public

\footnotetext{
${ }^{7}$ Debrun et al. (2008), Nerlich and Reuter (2013) and De Haan et al. (2013), for example, estimate similar regression equations.

${ }^{8}$ The Stata command xtbond2 written by Roodman (2009a) implements both these methods.
} 
finances may also adopt fiscal rules. This omitted variable bias is handled by the inclusion of fixed effects, as suggested by Foremny (2014).

The system GMM estimator uses internal instruments to handle the bias inherent in dynamic panel estimation. We assume in our empirical model that the fiscal rule index is exogenous. Although it could be the case that countries adopt fiscal rules as a response to insolvency problems, creating reverse causality running from the primary balance to rule adoption, this is unlikely contemporaneously. In particular, the inside lag (the time it takes for the government to identify insolvency problems and to design a policy response) is usually considerably longer than a year. We address potential reverse causality further, with additional empirical work, in the robustness section.

\section{DATA}

\subsection{Fiscal rules}

We use the IMF Fiscal Rules Dataset, as described in Schaechter et al. (2012), as our source of underlying data on fiscal rules. The IMF database covers all the EU countries for the sample 1985 to 2012 and includes detailed information on four types of rules: budget balance rules, debt rules, expenditure rules, and revenue rules. The IMF database does not include rules implemented at the sub-national level, only at the level of the central or general government. The dataset includes descriptions of the rules as well as information about the type of rule, year of implementation, number of rules, legal basis, coverage, monitoring, enforcement, institutional supporting features such as for example multi-year expenditure ceilings, and stabilization features such as budget balance rules accounting for the state of the economy. The underlying data is collected from many different sources; fiscal framework legislations, published and unpublished country documents, IMF staff reports and other IMF papers, information provided by national authorities, information provided by the EC, etc.

The IMF database is used to construct an overall index measuring the strength of fiscal rules in the EU member states as well as four specific fiscal rule measures - rules focusing on (i) balance budgets, (ii) expenditures, (iii) revenues, or (iv) debt limits. Following Schaechter et al. (2012), we construct indices reflecting five main characteristics of the fiscal rules, viz. monitoring, enforcement, coverage, the legal basis and escape clauses and use information concerning supporting procedures and institutions (multi-year expenditure ceilings implemented at the aggregate level, by ministry of by line item), whether there is an 
independent body setting budget assumptions, information about transparency and accountability, whether a balanced budget target is defined and whether there are rules excluding public investments or other priority items from the ceiling. In total, we then have 28 different characteristics describing national fiscal rules in each country. ${ }^{9}$

We add all 28 characteristics and renormalize the resulting index to be in the (theoretical) range between 0 and 4 . We use equal weights even though it could be argued that some rules or features may be more important than others. For countries having a rule, the fiscal rule index (FRI) mean value is 0.92, with a minimum value of 0.37 for Hungary in 2004-07 and a maximum value of 1.88 for the United Kingdom in 2012. In the 27 European Union countries over 1990-2012, only 2 countries had a national fiscal rule in place in 1990 (Germany and Belgium) and 16 had a fiscal rule in place in 2012 (Figure 1). Eight of the EU countries did not have a national fiscal rule in place at any time over the sample (Cyprus, Czech Republic, Greece, Ireland, Italy, Latvia, Malta, and Portugal), while 11 had no fiscal rule in place in 2012 (the preceding list plus Belgium, Hungary and Slovenia). Figure 2 shows the strength of the fiscal rules in place in 2012 for all of the EU countries at the time (Croatia joined in 2013). Fiscal rule strength for those with rules in 2012 ranged from 0.37 for the Slovak Republic to 1.88 for the United Kingdom.

- Figure 1 about here -

- Figure 2 about here -

- Figure 3 about here -

The left panel of Figure 3 shows the development over time, 1990-2012, of average fiscal rule strength for all EU countries and the separate developments for euro area (EA) members and non-EA members (EMU membership in 2012). This figure shows that the average strength of fiscal rules has grown markedly for the EU as a group and both the EA and those outside of the EA. However, a significant gap gradually emerged-- non-EA members had substantially stronger fiscal rules than euro area members by 2012.

\footnotetext{
${ }^{9}$ Many countries have national balanced budget rules and debt rules that also are supranational rules. In some countries, such as Austria and Spain, supranational rules in the form of balanced budget and debt rules were introduced first and then, at a later stage, these rules were implemented at the national level as well. When constructing our national fiscal rule strength indices, we take this into account.
} 
We also address which specific fiscal rules are most effective in promoting fiscal balance balanced budget rules, expenditure rules, revenue rules or debt rules. Using the IMF database we construct an index of the strength of the four types of rules, using a methodology similar to that used in constructing the aggregate index. For each type of rule we use equal weights for the characteristics of the specific rule into an index and then normalize such that the index is in the range of 0 to 4.14 of the $27 \mathrm{EU}$ countries had an expenditure rule at some point during the sample, reported in Table 1.

\section{- Table 1 about here -}

The median value of the index for countries with an expenditure rule is 1.5 (Finland has a value close to this in 2012). This is the most common specific rule amongst our four categories. Balanced budget rules were implemented at some point in 11 out of 27 countries. The median value of the index for countries with a balanced budget rule is 2.3. (Sweden had an index at this value in 2000). By contrast, the least popular fiscal rules in EU countries are revenue rules (only 5 out of 27 countries) and debt rules ( 8 out of 27 countries). The corresponding median value for countries implementing these rules is 2.7 (Netherlands, 2012) and 2.1 (United Kingdom, 2008), respectively.

The right panel of Figure 3 shows the development of fiscal rule strength for selected EU members-France, Germany, Spain and Sweden. Of this group, only Germany had fiscal rules in 1990 but all four fiscal rules of varying strength in 2012. These variations across time and in the levels of fiscal rule strength reflect how the character of individual fiscal rules differs across the EU countries and over time. For example, Sweden has had a balanced budget rule in place since 2000, defining a target surplus for the central government of $2 \%$ of GDP (2000-07) over the business cycle, and this is reflected in a jump in its rule index at that time. Sweden also operates an expenditure rule defining an expenditure ceiling for the central government and pension system set for a three-year period, adding one year annually. These ceilings cannot be adjusted except for technical issues and interest payments are excluded from the ceiling. To create a buffer, the government is using a budgetary margin which is automatically generated since almost all benefits are defined in nominal terms and not indexed. From 2007, the target fiscal surplus (over the business cycle) was changed to $1 \%$ of GDP in tandem with a number of rule strengthening actions such as creation of an independent fiscal policy council that evaluates compliance to the fiscal framework. As seen in Figure 3, another jump in Sweden's fiscal rule index occurred in 2007. 


\subsection{Government efficiency}

The "government efficiency" index used in our study is taken from the World Bank's "Worldwide Governance Indicators" (WGI), 2013 Update (see www.govindicators.org). ${ }^{10}$ This dataset consists of data on the efficiency of governance provided by a large number of enterprise, citizen and expert survey respondents in industrial and developing countries. These data are gathered from a number of survey institutes, think tanks, non-governmental organizations, international organizations, and private sector firms. The WGI consists of aggregate indicators of six broad dimensions of governance: (i) Voice and Accountability, (ii) Political Stability and Absence of Violence/Terrorism, (iii) Government Effectiveness, (iv) Regulatory Efficiency, (v) Rule of Law, and (vi) Control of Corruption. In their empirical analysis of alternative measures of government efficiency, Charron, Lapuente and Rothstein (2010) find that the World Bank data are both empirically and conceptually superior and provide the best measurement for reliable and meaningful comparisons of efficiency of government in the EU.

In short, the "Government Efficiency" indicator reflects perceptions of the efficiency of public services, the quality of the civil service and the degree of its independence from political pressures, the quality of policy formulation and implementation, and the credibility of the government's commitment to such policies. The government efficiency indicator ranges from around -2.5 to 2.5 , with higher values indicating greater government efficiency. The data on government efficiency is biannual from 1996 until 2002 and then annual. We use linear interpolation to add observations in 1997, 1999 and 2001 and in order to extend the data back to 1990 we make use of available data on an alternative measure of government efficiency, the International Country Risk Guide (ICRG). ${ }^{11}$

\subsection{Fiscal policy and control variables}

Our focus is on the determinants of fiscal solvency. We employ the cyclically-adjusted primary balance (PBCA) as our dependent variable. This measure of the budget balance filters out automatic stabilizers associated with business cycle fluctuations. The resultant

\footnotetext{
${ }^{10}$ See Kaufmann et al. (2010) for a detailed description of the methodology and analytical issues associated with construction and interpretation of the World Bank governance indicators.

${ }^{11}$ For details on how we extrapolate the World Bank data using the ICRG measure, see Appendix A2 in Bergman and Hutchison (2015).
} 
measure captures discretionary changes in fiscal policy and budget positions over the cycle, factors critical to longer-term fiscal sustainability. We use the measure of PBCA constructed by the European Commission. In the European context, the cyclically-adjusted budget balance is a critical part of the EU framework of fiscal surveillance, both in its preventive and corrective arms. ${ }^{12}$ This measure of fiscal solvency has been employed empirically in several studies (e.g., Debrun et al., 2008; Nerlich and Reuter, 2013).

Other factors might also lead to differences in fiscal performance across countries and across time. As control variables, we follow the extant literature and employ the lagged output gap, the lagged debt level, the dependency ratio, the degree of openness, the natural logarithm of population, and the rate of consumer price inflation. ${ }^{13}$ In line with the literature testing the effects of fiscal rules, we also include a number of political variables to control for differences in preferences across countries to fiscal institutions. The literature on the determinants of budget deficits (for example Woo, 2003, Mierau et.al., 2007 and de Haan et.al., 2013) as well as the literature on political business cycles (for example Klomp and de Haan, 2011) provide guidance. We use the fragmentation of government measured as the sum of the squared seat shares of all parties in the government, number of years left in current term, plurality dummy variable which is equal to 1 if the country has a plurality system, and an election year dummy variable which is equal to 1 if parliamentary election took place. These variables are taken from the World Bank Database of Political Institutions. Equation (1) with these control variables, and excluding the terms $F R I$ and $G E$ terms, is often referred to as the deficit bias regression, i.e., the response function of policy makers to economic as well as political variables.

In addition, following Hallerberg and von Hagen (1999), we add dummy variables representing the budget process. They show that European governments have developed different types of budget processes in order to promote fiscal discipline. Under delegation the minister of finance has been delegated agenda-setting powers in the preparation of the budget whereas under commitment, the budget process hinges on jointly negotiated and pre-

\footnotetext{
${ }^{12}$ Mourre et al. (2013) discuss the construction of the index and how the measure has been used to assess the fiscal policy stance in EU countries, especially in the context of recent reforms of European economic governance.

${ }^{13}$ This data and the cyclically adjusted primary balance are downloaded from the EC data base AMECO.
} 
established fiscal targets. We use the classifications in Hallerberg et al. (2007) for EU15, the classification for Central and Eastern European countries suggested by Yläoutinen (2004) and the classification of Gregor (2004) for Malta and Cyprus.

Finally, following Debrun et al. (2008), we introduce a dummy variable representing the run-up to EMU (RUNUP) equal to 1 for EU-15 countries and years between 1994 and 1998 and a dummy variable representing enlargement (Enlargement) which is equal to 1 for EU-10 countries after year 2003.

\section{EMPIRICAL RESULTS}

\subsection{Summary statistics}

Some suggestive evidence that fiscal rules may play a role in better fiscal performance is given in Table 2. The table reports some basic summary statistics for countries that have not adopted fiscal rules (top panel), countries that have adopted fiscal rules (middle panel) and for the full sample of countries (lower panel).

- Table 2 about here -

The differences between the groups with and without fiscal rules is striking, consistent and statistically significant at the $1 \%$ level: countries with fiscal rules (FRI) have much higher levels of government efficiency (GE; $1.45 \%$ versus $0.95 \%$ mean value), positive as opposed to negative cyclically-adjusted primary balances (PBCA; $0.78 \%$ versus $-0.30 \%$ ), much smaller net lending (cyclically-adjusted, NLCA; $-1.62 \%$ versus $-4.35 \%$ ), and substantially lower levels of government debt (Debt; 46\% versus 60\%). This suggests that both the strength of fiscal rules and also the efficiency of government may affect the sustainability of public finances in European Union countries.

\subsection{Baseline}

Table 3 reports fixed effects system GMM estimates of equation (1). ${ }^{14}$ Column (1) reports the regression with FRI as the focus variable and column (2) reports results with FRI, GE and their interaction as the focus variables. Both regressions include the full set of control variables discussed in the previous section (reported in appendix, Table A1).

\footnotetext{
${ }^{14}$ We consider alternative estimation methodologies in the robustness tests.
} 
- Table 3 about here -

In terms of the control variables, reported in Table A1, we find the expected results from the literature. All the coefficients have the expected signs and the majority is significant at the 10 percent level. The cyclically adjusted primary balance is strongly positively autocorrelated, justifying a dynamic specification. The lagged output gap (shortfall in output relative to potential) is negatively related to the primary balance - an increase in the output gap is associated with falling primary balance surpluses. Government debt has a positive significant effect - larger government debt leads to larger primary balance surpluses. The dependency ratio is positively (but insignificantly) related to primary balance surpluses such that countries with higher dependency ratio also tend to increase the primary balance. The effect of openness is positive and the effect of population (used as a proxy for the size of the economy) is negative. More open economies tend to have larger primary balance surpluses and larger countries smaller surpluses. Increasing inflation tends to increase primary balance surpluses.

Only two of the political variables are significant. Years in office have a positive effect, newly appointed governments tend to produce larger surpluses and, as election is closing in, surpluses are reduced. This is consistent with a political business cycle view where governments tend to expand the budget close to elections. The commitment dummy variable is positive, implying that this type of budget process leads to higher primary balance surpluses than countries adopting other budget processes.

In terms of the focus variables reported in Table 3, column (1) indicates that there is a strong positive effect on the cyclically-adjusted primary balance (PBCA) from fiscal rules (FRI). The point estimate is 0.83 and significant at the $5 \%$ level. As with the control variables, this result is also consistent with previous studies. Column (2) shows that the point estimate on FRI increases to 1.18 , the GE coefficient is positive as expected but insignificant, and the interaction term is negative and insignificant. However, the point estimate on FRI should be interpreted as the marginal effect when the GE value equals zero, and the point estimate on GE is the marginal effect when FRI equals zero. These point estimates convey little information since we are interested in a range of conditioning variables at values other than zero.

To capture the full interaction effect, where the effect of FRI on the primary balance is a function of different levels of GE, we calculate the marginal effects and confidence bands in 
Figure 4. ${ }^{15}$ We show the marginal effects for values of GE ranging from -0.6 to 2.4, corresponding to the minimum and maximum values of the variable in our sample (the mean value of GE is 1.17 and the median value of GE is 1.14).

- Figure 4 about here -

The marginal effects shown in Figure 4 are positive for all levels of GE but declining. This indicates that FRI and GE are policy/institutional substitutes, i.e. the marginal contribution of FRI in improving the primary balance PBCA falls as GE rises. The confidence bounds indicate that FRI has a statistically significant effect in improving the primary balance with levels of GE falling between -0.6 and 1.6. Once GE rises above 1.6, the marginal effect on the primary balance of increasing FRI is not statistically significant, i.e. high levels of government efficiency substitute for any additional effect of FRI on improving the primary balance.

To put these results in perspective, consider Ireland, Spain, and Sweden. The economies of Ireland and Spain suffered during the European debt crisis, experiencing high unemployment levels and weak economies, while Sweden has been amongst the best performers in Europe during this period. Sweden also has the "gold standard" in Europe of strong and transparent fiscal rules. In particular, these countries, in 2012, had debt levels (cyclically adjusted primary budget balance) as a percentage of GDP of $117 \%(-3.8 \%), 86 \%$ $(-5.2 \%)$ and $38 \%(1.5 \%)$. The fiscal rule indices for Ireland, Spain and Sweden in 2012, respectively, were zero, 1.03 and 1.42, fitting with the ranking of fiscal performance and rules. (Predicted values of the cyclically-adjusted primary budget for these countries, taken from column 2 of Table 3, are -4.6, -3.0 and 1.7, respectively.) Weaker fiscal rules are associated with higher debt and worse cyclically-adjusted budget positions (actual and predicted).

\subsection{Specific rule results}

Table 4 reports estimates of the basic model specification with the four specific rule indices (rather than the aggregate rule index) - expenditure, balanced budget, revenue and debt rule strength indices. As discussed above, these indices are constructed analogously to our

\footnotetext{
${ }^{15}$ See Brambor et al. (2006) for a detailed discussion and examples of the interpretation of marginal effects in regressions with discrete and continuous interaction terms.
} 
aggregate index but components are limited to the attributes applicable to the specific type of rule. Panel A reports the regressions with the specific rule indices and standard control variables (as in Table 3), but does not include government efficiency (GE). Panel B reports the regressions using specific rule indices combined with the efficiency of government, interaction terms and the standard control variables.

- $\quad$ Table 4 about here -

Panel A suggests that the type of rule matters for improved primary balance performance: balanced budget rules (BBR) and debt rules (DR) appear to be effective in increasing the primary balance, with both coefficients significantly positive at the $10 \%$ level of confidence. The effect of expenditure rules (ER) is marginally significant (significant at the $12 \%$ level with $\mathrm{t}$-value $=1.63$ ) and the effect is again positive. The strength of revenue rules $(\mathrm{RR})$, on the other hand, is clearly insignificant $(\mathrm{t}=-0.26)$.

Panel B reports the results when adding government efficiency and its interaction with the specific type of fiscal rule. The interpretation of the marginal effect of FRI is conditional upon the level of GE and best analyzed graphically, shown in Figure 5. Both expenditure rules and balanced budget rules are substitutes to government efficiency but there is a distinct difference in the marginal effects as government efficiency is increasing. For expenditure rules the marginal effect is positive and significant for levels of GE ranging from -0.6 to 1.2 whereas the effect of balanced budget rules is significant for GE ranging from 0.4 to the maximum value. Expenditure and balanced budget rules are generally helpful but their marginal effectiveness varies with the efficiency of government. Strong expenditure/balanced budget rules combined with highly efficient governments always support fiscal solvency, but at some threshold point substitutability between these institutional mechanisms is high.

- Figure 5 about here -

The figure also shows that the marginal effects on the primary balance from debt rules is increasing with government efficiency, suggesting that debt rules are complements to government efficiency. Debt rules only appear to be effective once GE quality reaches a minimum threshold level around unity (somewhat below the median value). As expected given the estimate shown in Panel A of Table 4, we find that the marginal effect of revenue rules is always insignificant. This could either be due to the fact that very few and quite 
diverse countries (Table 1) have adopted revenue rules or that this type of rule is more difficult to monitor and enforce.

Overall, the estimates reported in Table 4 and in Figure 5 suggest that rules are not all alike- the strength of the effect, the interaction with government efficiency and whether they are complements or substitutes to government efficiency differs. The results of Table 3 with the aggregate fiscal rule strength index suggest that rules and government efficiency are substitutes. However, when different types of rules are considered we find heterogeneity in their effects on primary balance.

First, revenue rules are not effective in reducing fiscal deficits. This is consistent with our priors set out in Section 2. Second the expenditure rule is effective (statistically significant) at a relatively high level of GE (1.1), and at that point the marginal effect on the fiscal balance is approximately 0.3 . Third, debt rules are similar to debt rules in that marginal effectiveness starts (statistically significant) at a GE level above 0.9 and, at that point, is associated with a marginal effect on the budget balance of about 0.2. An important difference between expenditure and debt rules, however, is that the former is a substitute with GE and the latter a complement with GE. Fourth, the balanced budget rule is very effective (marginal effect of 0.6) even at quite low levels of GE (0.1). In summary, balanced budget rules would appear the dominant rule - they are very effective even at low levels of government efficiency. At higher levels of government efficiency, expenditure and debt rules also help reduce deficit bias. But at no point do either of these rules marginally increase the cyclically-adjusted budget balance with the same force as the balanced budget rule.

Continuing the examples of Ireland, Spain and Sweden, these countries had balanced-budget rule indices of 0.0 (no rules), 1.73 and 3.07, respectively, in 2012. Correspondingly, their actual and predicted (from Table 4, panel B, column BBR) cyclically-adjusted primary balances were, respectively, $-3.8(-4.1),-5.2(-3.1)$ and $1.5(1.7)$. There is a clear distinction of rules and fiscal performance between Sweden, on the one hand, and Ireland and Spain, on the other hand. Ireland did not have fiscal rules in 2012 but ranked high in terms of government efficiency (GE index of 1.53). (Spain and Sweden had GE indices of 1.11 and 1.94, respectively, in 2012). Strong government efficiency helps Ireland in its quest for fiscal solvency. But our results indicate that fiscal performance would be greatly enhanced in Ireland if efficient government were complemented by effective fiscal rules-especially balanced budget rules. 


\subsection{Combinations of fiscal rules}

The estimates in the previous sub-section only reveal if and how a specific fiscal rule affects public finances. It may be the case that the effects on primary balance are strengthened when combining certain types of fiscal rules. For example, adopting both expenditure and revenue rules could be similar to having a balanced budget rule or a balanced budget rule may be a substitute to having a debt rule in force. To investigate this question we first construct a dummy variable indicating the number of fiscal rules in force in a particular country at each point in time. We define three dummy variables indicating the number of fiscal rules in a given year and country: one fiscal rule (if one fiscal rule in place the dummy equals unity, zero otherwise), two fiscal rules (if two rules in place the dummy is equal to unity, zero otherwise) and three fiscal rules (if three rules in place the dummy is equal to unity, zero otherwise). These dummy variables are non-overlapping meaning that if a country has two fiscal rules in place, then the dummy for one and three rules are zero and the dummy for two rules is equal to one. This allows us to make a direct comparison of point estimates.

The results from these tests are shown in Table 5. In the first column we add dummy variables as defined above indicating whether a country has one, two or three rules in force at the same time (together with the standard control variables).

- Table 5 about here -

We find a strong positive and significant effect on having any number of fiscal rules in force, and the effect is increasing with the number of fiscal rules. Testing whether these effects are indeed statistically different we find that we can reject the null that the effect of having one rule is equal to the effect of having two rules at the $10 \%$ level (F-test statistic equal to 3.39 with p-value equal to 0.077 ). On the other hand we find no additional effect of having three rules instead of only two (F-test statistic equal to 0.08 with p-value equal to 0.779). Finally, we test and reject the null hypothesis that all three parameters are equal at the $5 \%$ level (F-test statistic equal to 3.57 with p-value equal to 0.043). According to these results, countries already having a fiscal rule in place can achieve a stronger positive effect on primary balance surpluses by adopting one more fiscal rule. However, our results do not suggest that there is an additional effect by adding a third fiscal rule.

The empirical results above only reveal that the number of fiscal rules in force is important, not how rules should be combined in order to provide stronger effects on public finances. To 
investigate this issue, we run regressions using dummy variables for all types of fiscal rules and adding two types of rules in each regression including an interaction term indicating if both rules are in force.

The results are reported in the last three columns of Table $5 .{ }^{16}$ (We exclude revenue rules as they do not have significant effect on the primary balance). All three combinations of fiscal rules suggest sizable total effects on the primary balance, substantially larger than one standalone fiscal rule. Combinations of (a) expenditure rules and balanced budget rules and (b) balanced budget rules and debt rules indicate total effects of 1.34 and 1.42, respectively, while (c) an expenditure rule and debt rule combination indicates a total effect of 1.00 . These results indicate that multiple fiscal rules provide stronger fiscal discipline than one fiscal rule.

These results are supported by other regressions where the dummy variables used above are replaced with the sum of the fiscal strength index combinations (of the specific fiscal rule indices) together with GE, interaction terms, and the control variables.

These estimates, shown in Table 6 and in Figure 6, indicate that the combination of either an expenditure rule and a balanced budget rule, or a combination of an expenditure rule, a balanced budget rule and a debt rule, give significant and positive effects on the primary balance for virtually all levels of government efficiency in our sample. The former combination of rules is a substitute to government efficiency whereas the latter is a complement, i.e. the effect of a debt rule dominates the effect of a balanced budget rule. The other two combinations of rules we consider have positive effects on public finances (significant for relatively high levels of government efficiency) but the effect seems to be independent on the level of government efficiency.

- $\quad$ Table 6 about here -

- Figure 6 about here -

In summary, the number of fiscal rules in force and combination of rules play an important role on the overall effect on public finances and whether rules (and rule combinations) are complements or substitutes with government efficiency.

\footnotetext{
${ }^{16}$ In the second column, for example, Fiscal rule 1 refers to the ER dummy and Fiscal rule 2 refers to the BBR dummy variable (shown in the column heading). Sums of coefficients give total effects in the case of dummy variables.
} 


\section{Robustness Tests}

\subsection{Estimation methodology}

The baseline model is estimated using system GMM in a dynamic panel setting with fixed effects, a large set of control variables, and with both the fiscal rules index and government efficiency treated as exogenous variables. This estimator is well-suited in the presence of dynamic panel bias (involving panels with small $\mathrm{T}$ and large $\mathrm{N}$ ) and is a widely accepted methodology in this environment and the set of control variables is standard in the literature. However, it is useful to check the robustness of the results to alternative estimation methodologies. To this end, we report several alternative models and methodologies testing the robustness of our basic results in this section. In particular, we consider estimation of the model without fixed effects using both OLS and GMM methodologies, estimation of the model using Arellano-Bond one-step GMM, and system GMM treating GE as endogenous. Table 7 and Figure 7 report the estimates from the robustness tests.

- $\quad$ Table 7 about here -

- Figure 7 about here -

Fixed Effects. Much of the institutional variation in the sample is present in the crosssectional dimension of the data, partly captured by the fixed effects estimation strategy. This is the standard approach in the literature but may be criticized as capturing too much of the interesting variation in fiscal institutions and rules across countries. The disadvantage of focusing on cross-sections is the timing of the adoption of fiscal rules, which differ across countries and the continuous strengthening of the existing rules. And there may be time invariant differences in preferences for sustainable public finances across the European countries, such that countries with a preference for more stable public finances may also adopt fiscal rules. This omitted variable bias can be handled by the inclusion of fixed effects (Foremny, 2014).

To address whether the inclusion of fixed effects is driving our results, we report in the first and second columns in Table 7 (with marginal effects shown in the upper panels of Figure 7), the basic dynamic model (with controls) estimated without fixed effects using OLS (column 1) and GMM (column 2). 
The results are qualitatively very similar to the results reported in our baseline regressions (column 2 of Table 3 and Figure 4), although estimated with less precision. In all cases we find FRI positive and significant over a range of GE values, with a marginal effect that declines in magnitude as GE rises, i.e. high government efficiency is a substitute for fiscal rules. The $95 \%$ confidence level bands shown in Figure 7 suggest less precision of the estimates compared to the model with fixed effects (Figure 4). In particular, significant marginal effects of FRI on the budget balance (95\% confidence bounds) for our baseline model correspond to GE values ranging from -0.5 to 1.75 , while the corresponding GE range for the OLS (GMM) without fixed effects is about 0.25 to 1.75 (0.5 to 1.75 ).

System GMM and Arellano-Bond One-step Estimator. There is a broad discussion in the econometrics literature over the robustness of alternative GMM estimators when underlying estimation assumptions are not fully satisfied. ${ }^{17}$ Column (3) of Table 7 and the lower lefthand side of Figure 7 report results from estimating the basic model specification using the Arellano-Bond one-step GMM estimator rather than the system GMM estimator. Again, the results are qualitatively very similar to our baseline results, although the marginal effects are estimated with somewhat less precision.

\subsection{Measures of government efficiency, transparency and policy commitment}

Several alternative measures of government efficiency, transparency and government commitment to policy implementation are used in the literature. In this section we explore the robustness of our results to four of these measures. First, we consider the ICRG measure of government efficiency. Both our baseline (World Bank) measure of government efficiency and that of the ICRG are aggregate measures incorporating many different aspects of efficiency. However the ICRG measure is broader than GE. In particular, ICRG is an index consisting of a weighted average of the three indictors: corruption, law and order and bureaucracy quality ${ }^{18}$. (Our GE index is only reflecting bureaucratic quality.)

\footnotetext{
${ }^{17}$ See Bun and Sarafidis (2013) for a survey of alternative GMM estimation methods and their robustness.

${ }^{18}$ See International Country Risk Guide - The PRS Group http://www.prsgroup.com/ICRG.aspx for details.
} 
Second, we consider the Alt-Lassen-Wehner budget transparency index (Alt et al., 2014). ${ }^{19}$ This index is an aggregate of several transparency components: executive budget proposal with comprehensive expenditure and revenue figures and medium-term estimates; performance data; analysis of fiscal risks like deviations from key assumptions; in-year implementation updates; and reliable annual accounts that are independently audited (Alt et al., 2014; p. 8). The Alt-Lassen-Wehner index is not time-varying and therefore only reflects a (constant) ranking of budget transparency across the European countries.

Third, we investigate the government effectiveness measure developed by Institute for Management Development World Competitiveness Yearbook (WCY). This measure is a proxy for the governments' commitment to fiscal discipline broadly construed. The WCY measure is a composite index measuring (i) whether government economic policies adapt quickly to changes in the economy; (ii) whether the public service is independent from political interference; (iii) whether government decisions are effectively implemented; (iv) whether bureaucracy hinders business activity; (v) whether the distribution infrastructure of goods and services is generally efficient; and (vi) whether policy direction is consistent. This measure is available on a biannual basis from 1996 and annual from 2002. ${ }^{20}$ Fourth, we consider the most direct measure of policy commitment imbedded in the WCY index (subindex (iii)), that of whether government decisions are effectively implemented. We term this the "commitment" measure. This measure is available on a biannual basis from 1998 and annually from 2002.

We re-estimate equation (1) with each of these four measures, substituting for GE, and again adding all control variables (listed in Table A1). The results are reported in Table A2 and Figure 8. Our baseline results are robust to these alternative measures of government effectiveness (efficiency, transparency and commitment). The figure shows the marginal effects of fiscal rules as a function of the four different measures of government effectiveness. ${ }^{21}$ There is strong positive effect of fiscal rules on the cyclically-adjusted primary balance and a negative coefficient associated with the interaction of fiscal rules and

\footnotetext{
${ }^{19}$ See Appendix 2 in Alt et al. (2014). We use the interpolated transparency index in Table A1.

${ }^{20}$ This measure is one of the sub-indices published by the World Bank that is used in our broad aggregate measure of government efficiency (GE).

${ }^{21}$ The point estimates are shown in Table A2.
} 
the first three measures: ICRG (efficiency), Alt-Lassen (transparency) and WCY (broad commitment). This is consistent with our baseline results (Figure 4), indicating that fiscal rules are stronger in line with greater government effectiveness but that the marginal effect is declining. The confidence bands widen somewhat when using the Alt-Lassen-Wehner measure of transparency and the WCY measure of broad commitment, but the general qualitative results and the point estimates of the marginal effects are very similar to our baseline results.

On the other hand, the results shown in the lower right-hand side of Figure 8 - the marginal effect of fiscal rules at different levels of "commitment" to policy implementation - indicate a positive interaction effect, i.e. the combination of rules and commitment to policy is reinforcing and rising with higher degrees of commitment. Commitment appears to complement fiscal rules as opposed to substitute for fiscal rules as is the case for our other measures of government effectiveness or transparency. Moreover, the overall net effect is very strong. For example, a median level of the commitment index (0.41) gives a marginal effect of rules of 1.66. The corresponding median values and marginal effects of rules for ICRG efficiency, Alt-Lassen transparency and WCY broad commitment are $(0.80,0.64$, $0.47)$ and (0.82, 0.85 and 1.09), respectively.

\subsection{EA membership and SGP fiscal rules}

The effectiveness of national fiscal rules may be influenced by membership in the euro area (EA) where countries are automatically subject to, but may not follow, the deficit and debt limits embodied in the Stability and Growth Pact (SGP). ${ }^{22}$ On the one hand, the SGP may weaken national fiscal rules since they may be viewed as redundant and unnecessary. On the other hand, the SGP may reinforce and strengthen the effectiveness of national fiscal rules to the extent that the SGP rules are stronger and are monitored externally by the European Commission. Nerlich and Reuter (2013) investigate the effect of euro adoption on the cyclically-adjusted primary balance, interpreting EA membership as being subject to the strict rules of the SGP. They find that membership in the euro worsens the budget balance

\footnotetext{
${ }^{22}$ In principle, the SGP applies to all EU member states but the monitoring and procedures for warning and penalties are more explicit and stronger for the EU states adopting the euro.
} 
and argue that the disciplinary device for countries that wish to join the euro area is considerably stronger than for those already in the euro area.

In this vein, and focusing on the marginal effectiveness of national fiscal rules, we include EA membership (dummy variable) and its interaction with the national fiscal rule strength index. (In our panel data set, the EA membership dummy variable value of unity starts on the year in which the country formally joined the EA, and is zero prior to that time.) The effect of national fiscal rules on reducing the primary balance is not affected by inclusion of the EA terms, i.e. our main result in not changed (Table A2). Consistent with Nerlich and Reuter (2013), EA membership is negatively associated with the fiscal balance (but only significant at the $16 \%$ level). The interaction term, our focus of interest, is positive but statistically insignificant. This suggests that a given level of national fiscal rule strength is as effective in reducing the fiscal deficit when countries participate in the EA as when countries remain outside the monetary union.

In particular, the total effect of fiscal rules for EA members is 0.98 (significant at the 10 percent level) but not significantly different from the estimate for countries outside the monetary union which is 0.74 (significant at the 5 percent level). EA membership and exposure to the SGP supranational fiscal rules does not influence the effectiveness of national fiscal rules.

\subsection{Endogeneity}

Countries may adopt fiscal rules as a response to a history of insolvency problems. This may create reverse causality running from public finance to the adoption of fiscal rules. In our empirical model we have included a range of political and institutional variables that are used as instruments when estimating the effects of fiscal rules on the primary balance. Contemporaneous reverse causality from public finances to the adoption of fiscal rules is unlikely since the inside lag (the time it takes for the government to identify insolvency problems and to design a policy response) is considerably longer than a year. However, a country suffering from a long period of large deficits and soring government debt may decide to adopt fiscal rules as part of a fiscal consolidation program or as a policy to prevent future insolvency problems.

We have conducted a range of tests to shed light on this particular endogeneity problem, i.e., whether fiscal rules are endogenous and implemented as a consequence of a history of 
sovereign solvency problems. ${ }^{23}$ We have run standard OLS regressions where we have the strength of fiscal rules as dependent variable and the cyclically-adjusted primary balance as independent variable and adding all control variables used in the regressions reported in Table 7. Allowing for up to 5 lags of primary balance, these regressions show that we cannot reject the null that the parameters associated with primary balance are equal to zero using conventional significance levels. ${ }^{24}$

Another concern is that government efficiency may be endogenous with the primary budget balance. A possible reason is that the World Bank data is based on surveys implying that a government running large budget deficits and allows government debt to increase sharply may be considered as an ineffective government by the respondents of the survey. This creates reverse causality running from public finances to government efficiency. In column (4) of Table 7 (and the lower right-hand side panel of Figure 7) we report results of the system GMM regression with the basic model assuming that government efficiency is endogenous, thus using variations of it as GMM instruments. Our general conclusions are unaffected: the results are robust to the assumption that government efficiency is endogenous instead of exogenous as we assume in our base case. However, the precision of the estimates is somewhat weaker than in the baseline case. In particular, FRI is significant over the 0 to 1.25 level of GE at the $95 \%$ level of confidence in these estimates.

In another iteration of the model addressing causal timing, we assume that government efficiency and fiscal rules have lagged effects on the primary balance, not the contemporaneous effect assumed in our base model. Again the main results are not affected. ${ }^{25}$ Overall, our empirical results are robust to alternative estimation methods, changes in our

\footnotetext{
${ }^{23}$ These results are not reported here for brevity but are available in a supplement to the paper made available from the authors upon request.

${ }^{24}$ We also consider Probit regressions where we model the probability of having fiscal rules following Calderón and Schmidt-Hebbel (2008), IMF (2009) and Elbadawi et al. (2014). Estimating similar models for the $27 \mathrm{EU}$ countries in our sample and allowing for lagged effects of up to 3 years we find no empirical evidence suggesting that the probability of having fiscal rules is significantly determined by past performance of public finances (cyclically adjusted primary balance and government debt). We follow Samarina and de Haan (2014) in estimating a panel Probit model but focusing on the determinants involving in the choice to adopt a fiscal rule. We find no empirical evidence that fiscal rules are adopted as a response to recent deficit or debt developments. These results are available from the authors upon request.

${ }^{25}$ These results are not reported for brevity but available upon request from the authors.
} 
assumptions about the endogeneity of government efficiency and the timing of government efficiency and fiscal rules.

\section{CONCLUSions}

In this paper we have taken a closer look at the track record of fiscal rules implemented at the national level in the EU. We investigate whether fiscal rules adequately reflect de facto constraints on public finances, and whether the effectiveness of rules is affected by the institutional environment in which they are designed and implemented. To this end, we construct five new fiscal rule strength indices from an IMF Fiscal Affairs Division database. We construct an aggregate fiscal rule strength index, as well as four rule-specific indices (balanced budget, debt, expenditure and revenue rules), based on distinct characteristics of actions, legislative or procedural, that constrain fiscal policy actions in each country at each point in time.

We investigate whether aggregate or specific types of rules in the EU are effective in limiting fiscal deficits, measured by the cyclically-adjusted primary budget balance, and whether the effects of national fiscal rules depend on institutional characteristics: the degree of government efficiency, transparency and policy commitment. In particular, we test whether the effects of fiscal rules are stronger when combined with stronger institutions. We employ dynamic panel methods for the 27 EU countries over 1990-2012. In all of these investigations, we measure the marginal effects of national fiscal rules, aggregate and specific-types of rules, while conditioning on a range of economic and political factors.

We find that stronger national fiscal rules are associated with more sustainable fiscal policies, and that this effect holds over a large spectrum of government efficiency characteristics, policy transparency and policy commitment. Commitment to fiscal sustainability is particularly important in the enforcement of rules. Balanced rules seem to dominate over expenditure and debt rules, but all three are effective in reducing the deficit bias as long as a minimum level of government efficiency is obtained. Implementing more than one fiscal rule gives an additional improvement of the primary balance. Exposure to the SGP does not influence the effectiveness of national rules in reducing the deficit bias. Our empirical results are robust to alternative estimation methods, changes in our assumptions about the endogeneity of government efficiency and the timing of government efficiency and fiscal rules. 
Finally, one could ask how well the Fiscal Compact (FC), the new EU rules on public finances introduced by March 2012, fit with the "best practices" uncovered by our empirical work. The answer is: surprisingly well. A key part of the FC is to make the (revised) supranational rules of the SGP into national fiscal rules, the main rule being a balanced budget rule in the form of a structural deficit of $0.5 \%$ over the medium term. ${ }^{26}$ A key finding of this paper is that a balanced budget rule is clearly the most effective rule in reducing the deficit bias. Our empirical work further supports the FC measures to strengthen the balanced budget rule with complementary measures, such as independent bodies to enforce and monitor rules (leading to a stronger rule index), clear transparency and government commitment to implement policies. On balance, all of these features of the Fiscal Compact will likely reduce deficit bias in the EU.

\section{Acknowledgements}

Without implication, we thank Iain Begg, Manuele Citi, David Dreyer Lassen, Bent E. Sørensen, two anonymous referees, the editor of this journal and conferences/seminar participants for many valuable comments and suggestions.

\footnotetext{
${ }^{26}$ The FC allows for $1 \%$ structural deficit if the country has a low debt level, and the FC specifies acceptable periods of adjustment toward the fiscal target, monitoring and enforcement procedures, independence of the institutions responsible at the national level for monitoring compliance with the rules, and so on.
} 


\section{REFERENCES}

Afonso, A., Guimarães, A.S., 2014. The Relevance of Fiscal Rules for Fiscal and Yield Developments. Working Papers 05/2014. Lisboa School of Economics \& Management.

Afonso, A., Hauptmeier, S., 2009. Fiscal Behaviour in the European Union: Rules, Fiscal Decentralization and Government Indebtedness. Working Paper Series 1054. European Central Bank.

Albuquerque, B., 2011. Fiscal Institutions and Public Spending Volatility in Europe. Economic Modelling. 28, 2544-2559.

Alesina, A., Tabellini, G., 1990. A Positive Theory of Fiscal Deficits and Government Debt. The Review of Economic Studies. 57, 403-414.

Alt, J., Lassen, D.D., Wehner, J., 2014. It isn't Just about Greece: Domestic Politics, Transparency and Fiscal Gimmikry in Europe. British Journal of Political Science. 44, 707-716.

Ayuso-i-Casals, J., 2012. National Expenditure Rules: Why, How and When. Economic Papers 473. European Commission.

Beetsma, R., Debrun, X., 2005. Implementing the Stability and Growth Pact: Enforcement and Procedural Flexibility. IMF Working Paper No. 05/59.

Beetsma, R., Debrun, X., 2004. Reconciling Stability and Growth: Smart Pacts and Structural Reforms. IMF Staff Papers. 51, 431-456.

Beetsma, R., Uhlig, H., 1999. An Analysis of the Stability and Growth Pact. The Economic Journal. 109, 546-571.

Bergman, U.M., Hutchison, M.M., 2015. Economic Stabilization in the Post-Crisis World: Are Fiscal Rules the Answer?. Journal of International Money and Finance. 52, 82-101.

Blundell, R., Bond, S., 1998. Initial Conditions and Moment Restrictions in Dynamic Panel Data Models. Journal of Econometrics. 87, 115-143.

Bontempi, M.E., Mammi, I., 2012. A Strategy to Reduce the Count of Moment Conditions in Panel Data GMM. MPRA Paper No. 40720.

Brambor, T., Clark, W.R., Golder, M., 2006. Understanding Interaction Models: Improving Empirical Analyses. Political Analysis. 14, 63-82.

Bun, M., Sarafidis, V., 2013. Dynamic Panel Data Models. Discussion Paper 2013/01. Amsterdam School of Economics.

Calderón, C., Duncan, R., Schmidt-Hebbel, K., 2012. Do Good Institutions Promote Counter-Cyclical Macroeconomic Policies?. Working Paper No. 118 (June). Federal Reserve Bank of Dallas Globalization and Monetary Policy Institute.

Calderón, C., Schmidt-Hebbel, K., 2008. The Choice of Fiscal Regime in the World. Working Paper No. 487. Central Bank of Chile.

Charron, N., Lapuente, V., Rothstein, B., 2010. Measuring the Quality of Government and Subnational Variation. Report for the European Commission Directorate-General Regional Policy Directorate Policy Development.

Corbacho, A., Schwartz, G., 2007. Fiscal Responsibility Laws, in Kumar, M., Ter-Minassian, T., (Eds.), Promoting Fiscal Discipline. International Monetary Fund, Washington DC.

Dahan, M., Strawczynski, M., 2010. Fiscal Rules and Composition Bias in OECD Countries. CESifo Working Paper Series 3088. CESifo Group Munich. 
de Haan, J., Jong-A-Pin, R., Mierau, J.O., 2013. Do Budgetary Institutions Mitigate the Common Pool Problem? New Empirical Evidence for the EU. Public Choice. 156, 423-441.

Debrun, X., Moulin, L., Turrini, A., Ayuso-i-Casals, J., Kumar, M.S., 2008. Tied to the Mast? National Fiscal Rules in the European Union. Economic Policy. 23, 297-362.

Elbadawi, I.A., Schmidt-Hebbel, K., Soto, R., 2014. Why Do Countries Have Fiscal Rules?. Working Paper No. 452. Instituto de Economia, Pontificia Universidad Catolica De Chile.

Foremny, D., 2014. Sub-national Deficits in European Countries: The Impact of Fiscal Rules and Tax Autonomy. Journal of European Political Economy. 34, 86-110.

Frankel, J., Vegh, C., Vuletin, G., 2013. On Graduation from Fiscal Procyclicality. Journal of Development Economics. 100, 32-47.

Girouard, N., André, C., 2005. Measuring cyclically-adjusted budget balances for OECD countries. OECD Economics Department Working Papers. No. 434, OECD Publishing. http://dx.doi.org/10.1787/787626008442.

Gregor, M., 2004. Governing Fiscal Commons in the Enlarged EU. Working Papers IES 56. Institute of Economic Studies, Faculty of Social Sciences, Charles University Prague.

Hall, A.R., Peixe, F.P.M., 2003. A Consistent Method for the Selection of Relevant Instruments. Econometric Reviews. 22, 269-287.

Hallerberg, M., von Hagen, J., 1999. Electoral Institutions, Cabinet Negotiations, and Budget Deficits in the European Union, in Poterba, J., von Hagen, J., (Eds.), Fiscal Institutions and Fiscal Performance. University of Chicago Press.

Hallerberg, M., Strauch, R., von Hagen, J., 2007. The Design of Fiscal Rules and Forms of Governance in European Union Countries. European Journal of Political Economy. 23, 338-359.

Holm-Hadulla, F., Hauptmeier, S., Rother, P., 2012. The Impact of Expenditure Rules on Budgetary Discipline over the Cycle. Applied Economics. 44, 3287-3296.

Hughes Hallett, A., Jensen, S.H., 2012. Fiscal Governance in the Euro Area: Institutions vs. Rules. Journal of European Public Policy. 19, 646-664.

Iara, A., Wolff, G., 2014. Rules and Risk in the Euro Area. European Journal of Political Economy. $34,222-236$.

International Monetary Fund, 2009. Fiscal Rules - Anchoring Expectations for Sustainable Public Finances. Fiscal Affairs Department, IMF, Washington DC.

Kaufmann, D., Kraay, A., Mastruzzi, M., 2010. The Worldwide Governance Indicators: Methodology and Analytical Issues. World Bank Policy Research Working Paper No. 5430 (September).

Klomp, J., de Haan, J., 2011. Do political budget cycles really exist?. Applied Economics. 45, 329341.

Krogstrup, S., Wyplosz, C., 2010. A Common Pool Theory of Supranational Deficit Ceilings. European Economic Review. 54, 269-278.

Lavigne, R., 2011. The Political and Institutional Determinants of Fiscal Adjustment: Entering and Exiting Fiscal Distress. European Journal of Political Economy. 27, 17-35.

Mierau, J.O., Jong-A-Pin, R., de Haan, J., 2007. Do Political Variables Affect Fiscal Policy Adjustment Decisions? New Empirical Evidence. Public Choice. 133, 297-319.

Mourre, G., Isbasoiu, G., Paternoster, D., Salto, M., 2013. The Cyclically-adjusted Budget

Balance used in the EU Fiscal Framework: an update. European Commission European Economy Economic Papers 478 (March). 
Muscatelli, V., Natale, P., Tirelli, P., 2012. A Simple and Flexible Alternative to the Stability and Growth Pact Deficit Ceilings. Is it at hand?. European Journal of Political Economy. 28, 14-26.

Nerlich, C., Reuter, W.H., 2013. The Design of National Fiscal Frameworks and their Budgetary Impact. ECB Working Paper Series No. 1588.

Persson, M., Persson, T., 1987. Time Consistency of Fiscal and Monetary Policy. Econometrica. 55, 1419-1431.

Persson, M., Persson, T., Svensson, L., 2006. Time Consistency of Fiscal and Monetary Policy: A Solution. Econometrica. 74, 193-212.

Persson, T., Svensson, L., 1989. Why a Stubborn Conservative would Run a Deficit: Policy with Time- Inconsistent Preferences. The Quarterly Journal of Economics. 104, 325-345.

Primo, D., 2006. Stop Us Before We Spend Again: Institutional Constraints on Government Spending. Economics \& Politics. 18, 269-312.

Roodman, D., 2009a. How to do xtabond2: An Introduction to Difference and System GMM in Stata, Stata Journal. 9, 86-136.

Roodman, D., 2009b. A Note on the Theme of Too Many Instruments. Oxford Bulletin of Economics and Statistics. 71, 135-158.

Sacchi, A., Salotti, S., 2015. The Impact of National Fiscal Rules on the Stabilisation Function of Fiscal Policy. European Journal of Political Economy. 37, 1-20.

Samarina, A., de Haan, J., 2014. Right on Target: Exploring the Factors Leading to Inflation Targeting Adoption. Contemporary Economic Policy. 32, 372-389.

Schaechter, A., Kinda, T., Budina, N., Weber, A., 2012. Fiscal Rules in Response to the Crisis Toward the "Next-Generation" Rules. A New Dataset. IMF Working Paper 12/187.

Schuknecht, L., Moutot, P., Rother, P., Stark, J., 2011. The Stability and Growth Pact: Crisis and Reform. Occasional Paper Series No. 129. European Central Bank, Frankfurt.

Velasco, A., 2000. Debts and Deficits with Fragmented Fiscal Policymaking. Journal of Public Economics. 76, 105-125.

von Hagen, J., Harden, I.J., 1995. Budget Processes and Commitment to Fiscal Discipline. European Economic Review. 39, 771-779.

Weingast, B., Shepsle, K., Johnsen, C., 1981. The Political Economy of Benefits and Costs: A Neoclassical Approach to Distributive Politics. Journal of Political Economy. 89, 642-664.

Wierts, P., 2008. Fiscal rules and fiscal outcomes in EMU - Theory and evidence. PhD thesis. University of Reading.

Windmeijer, F., 2005. A Finite Sample Correction for the Variance of Linear Efficient Two-step GMM Estimators. Journal of Econometrics. 126, 25-51.

Woo, J., 2003. Economic, political, and institutional determinants of public deficits. Journal of Public Economics. 87, 387-426.

Wyplosz, C., 2005. Fiscal Policy: Institutions versus Rules. National Institute Economic Review. 191, $70-84$.

Yläoutinen, S., 2004. The Role of Electoral and Party Systems in the Development of Fiscal Institutions in the Central and Eastern European Countries. ZEI Working Papers B 13-2004. ZEI Center for European Integration Studies, University of Bonn. 
Table 1. Countries that have implemented specific fiscal rules during the sample period 1990-2012 (at least one year)

\begin{tabular}{llll}
\hline $\begin{array}{l}\text { Expenditure Rule } \\
(\mathbf{1 4 / 2 7})\end{array}$ & $\begin{array}{l}\text { Balanced budget } \\
\text { rule (11/27) }\end{array}$ & Revenue rule (5/27) & Debt rule (8/27) \\
\hline Belgium & Austria & Belgium & Bulgaria \\
Bulgaria & Bulgaria & Denmark & Finland \\
Denmark & Denmark & France & Lithuania \\
Finland & Estonia & Lithuania & Luxembourg \\
France & Finland & Netherlands & Poland \\
Germany & Germany & & Slovak Republic \\
Hungary & Hungary & & Slovenia \\
Lithuania & Poland & & UK \\
Luxembourg & Spain & & \\
Netherlands & Sweden & & \\
Poland & UK & \\
Romania & & & \\
Spain & & & \\
Sweden & & & \\
\hline \hline
\end{tabular}

Table 2. Descriptive Statistics: European countries with and without fiscal rules

\begin{tabular}{lllllll}
\hline \hline & & Mean & Median & StdDev. Min & \multicolumn{1}{l}{ Max } \\
\hline No Fiscal Rule & FRI & 0 & 0 & 0 & 0 & 0 \\
& GE & 0.955 & 0.913 & 0.622 & -0.623 & 2.010 \\
& PBCA & -0.301 & -0.163 & 3.587 & -25.018 & 11.923 \\
& NLCA & -4.358 & -3.970 & 3.395 & -28.165 & 3.274 \\
& Debt & 60.390 & 57.524 & 32.576 & 6.576 & 170.305 \\
\hline At Least One Fiscal Rule & FRI & 0.917 & 0.871 & 0.394 & 0.371 & 1.886 \\
& GE & 1.466 & 1.729 & 0.649 & -0.314 & 2.357 \\
& PBCA & 0.783 & 0.874 & 2.931 & -7.969 & 9.489 \\
& NLCA & -1.623 & -1.557 & 3.015 & -11.866 & 5.805 \\
& Debt & 46.328 & 47.071 & 26.208 & 3.685 & 134.067 \\
\hline Total & FRI & 0.383 & 0.000 & 0.519 & 0.000 & 1.886 \\
& GE & 1.168 & 1.139 & 0.681 & -0.623 & 2.357 \\
& PBCA & 0.213 & 0.216 & 3.334 & -25.018 & 11.923 \\
& NLCA & -3.062 & -3.034 & 3.496 & -28.165 & 5.805 \\
& Debt & 53.892 & 52.426 & 30.593 & 3.685 & 170.305 \\
\hline \hline
\end{tabular}


Table 3. The effect of government efficiency and fiscal rules on the cyclically-adjusted primary balance.

\begin{tabular}{lcc}
\hline \hline & $(\mathbf{1})$ & $(\mathbf{2})$ \\
\hline FRI & $0.831^{* *}$ & $1.181^{* *}$ \\
& $(0.341)$ & $(0.524)$ \\
GE & & 0.464 \\
& & $(0.389)$ \\
FRI * GE & & -0.310 \\
& & $(0.339)$ \\
\#countries & 27 & 27 \\
\#instruments & 19 & 21 \\
Obs & 502 & 502 \\
AR(1) & 0.013 & 0.013 \\
AR(2) & 0.339 & 0.328 \\
Hansen & 0.440 & 0.390
\end{tabular}

Note: FRI (GE) is the fiscal rules (government efficiency). System GMM estimates. A constant and all control variables are also included in the regressions but not shown here for brevity. AR(1) and AR(2) are tests of autocorrelation of the first and second order, respectively. Only p-values are reported for the Hansen J overidentifying tests and the two tests for autocorrelation. Clustered and robust standard errors reported below each estimate. $* * *$ denotes significant at the $1 \%$ level, $* *$ at the $5 \%$ level and $*$ at the $10 \%$ level. Point estimates and standard errors of control variables are listed in Appendix Table A1. 
Table 4. The effect of government efficiency and specific fiscal rules on the cyclicallyadjusted primary balance.

\begin{tabular}{|c|c|c|c|c|}
\hline \multicolumn{5}{|l|}{ Panel A } \\
\hline & ER & BBR & $\mathbf{R R}$ & DR \\
\hline \multirow[t]{2}{*}{ Fiscal rule index } & 0.266 & $0.480 * * *$ & -0.021 & $0.202 *$ \\
\hline & $(0.163)$ & $(0.128)$ & $(0.080)$ & $(0.107)$ \\
\hline \#countries & 27 & 27 & 27 & 27 \\
\hline \#instruments & 19 & 19 & 19 & 19 \\
\hline Obs & 502 & 502 & 502 & 502 \\
\hline $\mathrm{AR}(1)$ & 0.013 & 0.015 & 0.013 & 0.013 \\
\hline $\operatorname{AR}(2)$ & 0.323 & 0.369 & 0.339 & 0.340 \\
\hline Hansen & 0.449 & 0.525 & 0.482 & 0.469 \\
\hline \multicolumn{5}{|l|}{ Panel B } \\
\hline \multirow[t]{2}{*}{ Fiscal rule index } & $0.617 * *$ & $0.667 *$ & -0.214 & 0.021 \\
\hline & $(0.237)$ & $(0.361)$ & $(0.206)$ & $(0.176)$ \\
\hline \multirow[t]{2}{*}{ GE } & $0.622^{*}$ & 0.422 & $0.559 *$ & 0.446 \\
\hline & $(0.311)$ & $(0.328)$ & $(0.293)$ & $(0.366)$ \\
\hline \multirow[t]{2}{*}{ Fiscal rule index $* \mathrm{GE}$} & $-0.291 *$ & -0.154 & 0.096 & 0.200 \\
\hline & $(0.158)$ & $(0.183)$ & $(0.155)$ & $(0.146)$ \\
\hline \#countries & 27 & 27 & 27 & 27 \\
\hline \#instruments & 21 & 21 & 21 & 21 \\
\hline Obs & 502 & 502 & 502 & 502 \\
\hline $\mathrm{AR}(1)$ & 0.013 & 0.014 & 0.013 & 0.013 \\
\hline $\mathrm{AR}(2)$ & 0.311 & 0.354 & 0.315 & 0.312 \\
\hline Hansen & 0.379 & 0.487 & 0.470 & 0.437 \\
\hline
\end{tabular}

Note: System GMM estimates. A constant is also included in the regressions and all control variables in Table 4 but these estimates are not shown here for brevity. $\operatorname{AR}(1)$ and $\operatorname{AR}(2)$ are tests of autocorrelation of the first and second order, respectively. Only p-values are reported for the Hansen J over-identifying tests and the two tests for autocorrelation. Clustered and robust standard errors reported below each estimate. *** denotes significant at the $1 \%$ level, ** at the $5 \%$ level and * at the $10 \%$ level. 
Table 5. The effect of combinations of specific fiscal rules on cyclically-adjusted primary balance.

\begin{tabular}{lcccc}
\hline \hline & Number of fiscal rules & ER \& BBR & ER \& DR & BBR \& DR \\
\hline One fiscal rule & $0.640^{* *}$ & & & \\
& $(0.275)$ & & & \\
Two fiscal rules & $1.141^{* *}$ & & & \\
& $(0.417)$ & & & \\
Three fiscal rules & $1.245^{* * *}$ & & & \\
& $(0.389)$ & & & \\
Fiscal rule 1 & & $0.624^{*}$ & $0.696^{*}$ & $1.136^{* * *}$ \\
& & $(0.307)$ & $(0.370)$ & $(0.329)$ \\
Fiscal rule 2 & & $1.152^{* * *}$ & $0.786^{* *}$ & $0.721^{* *}$ \\
& & $(0.249)$ & $(0.357)$ & $(0.279)$ \\
Interaction & & -0.434 & -0.474 & -0.437 \\
& & $(0.388)$ & $(0.550)$ & $(0.358)$ \\
Total effect & & $1.342^{* * *}$ & $1.007 * * *$ & $1.420^{* * *}$ \\
& & $(0.436)$ & $(0.253)$ & $(0.309)$ \\
\#countries & 0.319 & 27 & 27 & 27.000 \\
\#instruments & 0.440 & 0.459 & 0.439 & 0.495 \\
Obs & 21 & 502 & 502 & 502 \\
AR(1) & 502 & 0.014 & 0.013 & 0.014 \\
AR(2) & & 0.316 & 0.343 \\
Hansen & & & 21 & 21 \\
\hline
\end{tabular}

Note: System GMM estimates. Fiscal rule 1 refers to the first type of fiscal rule in the header of the paper whereas fiscal rule 2 refers to the second type of rule in the header. Total effect is the sum of the impact when both rules are in force. A constant and all control variables are also included in the regressions but not shown here for brevity. $\mathrm{AR}(1)$ and $\mathrm{AR}(2)$ are tests of autocorrelation of the first and second order, respectively. Only pvalues are reported for the Hansen J over-identifying tests and the two tests for autocorrelation. Clustered and robust standard errors reported below each estimate. ${ }^{* * *}$ denotes significant at the $1 \%$ level, $* *$ at the $5 \%$ level and $*$ at the $10 \%$ level. 
Table 6. The effect of government efficiency and combinations of specific fiscal rules on the cyclically-adjusted primary balance.

\begin{tabular}{lcccc}
\hline \hline & FRI_ERBBR & FRI_ERDR & FRI_BBRDR FRI_ERBBRDR \\
\hline Fiscal rule index & $0.615^{* * * *}$ & $0.207^{*}$ & 0.208 & $0.273^{* *}$ \\
& $(0.208)$ & $(0.107)$ & $(0.166)$ & $(0.110)$ \\
GE & 0.418 & 0.483 & 0.353 & 0.335 \\
& $(0.336)$ & $(0.370)$ & $(0.367)$ & $(0.369)$ \\
Interaction term & -0.175 & -0.004 & 0.059 & -0.005 \\
& $(0.115)$ & $(0.105)$ & $(0.091)$ & $(0.064)$ \\
\#countries & 27 & 27 & 27 & 27 \\
\#instruments & 21 & 21 & 21 & 21 \\
Obs & 502 & 502 & 502 & 502 \\
AR(1) & 0.014 & 0.013 & 0.014 & 0.013 \\
AR(2) & 0.337 & 0.308 & 0.337 & 0.326 \\
Hansen & 0.392 & 0.424 & 0.479 & 0.437 \\
\hline \hline
\end{tabular}

Note: System GMM estimates. A constant and all control variables are also included in the regressions but not shown here for brevity. AR(1) and AR(2) are tests of autocorrelation of the first and second order, respectively. Only p-values are reported for the Hansen J over-identifying tests and the two tests for autocorrelation. Clustered and robust standard errors reported below each estimate. *** denotes significant at the $1 \%$ level, ** at the $5 \%$ level and $*$ at the $10 \%$ level. 
Table 7. Estimation Methodology Robustness Tests

\begin{tabular}{lcccc}
\hline \hline & $\begin{array}{c}\text { OLS no fixed } \\
\text { effects }\end{array}$ & $\begin{array}{c}\text { GMM no fixed } \\
\text { effects }\end{array}$ & $\begin{array}{c}\text { AB one-step } \\
\text { GMM }\end{array}$ & $\begin{array}{c}\text { System GMM, GE } \\
\text { endogenous }\end{array}$ \\
\hline FRI & $0.809^{*}$ & 0.644 & $2.193^{*}$ & $1.953^{*}$ \\
GE & $(0.428)$ & $(0.407)$ & $(1.080)$ & $(0.989)$ \\
& $0.676^{*}$ & $0.585^{*}$ & -0.137 & 1.839 \\
FRI*GE & $(0.342)$ & $(0.345)$ & $(1.192)$ & $(1.478)$ \\
& -0.201 & -0.085 & -0.814 & -1.073 \\
Constant & $(0.250)$ & $(0.237)$ & $(0.626)$ & $(0.756)$ \\
& $-2.025^{*}$ & $-2.427^{* *}$ & & -2.739 \\
\#countries & $(1.010)$ & $(1.206)$ & & $(2.700)$ \\
\#instruments & & 27 & 27 & 27 \\
\#obs & & 21 & 19 & 23 \\
AR(1) & 502 & 0.365 & 473 & 502 \\
AR(2) & & 0.489 & 0.003 & 0.015 \\
Hansen & & 0.330 & 0.303 \\
\hline \hline
\end{tabular}

Note: Dependent variables is the cyclically-adjusted primary balance (percentage of GDP). FRI (GE) is the fiscal rules (government efficiency). A constant and all control variables are also included in the regressions but not shown here for brevity. $\operatorname{AR}(1)$ and $\operatorname{AR}(2)$ are tests of autocorrelation of the first and second order, respectively. Only p-values are reported for the Hansen J over-identifying tests and the two tests for autocorrelation. Clustered and robust standard errors reported below each estimate. *** denotes significant at the $1 \%$ level, ** at the $5 \%$ level and * at the $10 \%$ level. 
Figure 1. Number of countries with at least one fiscal rule in force in a given year.

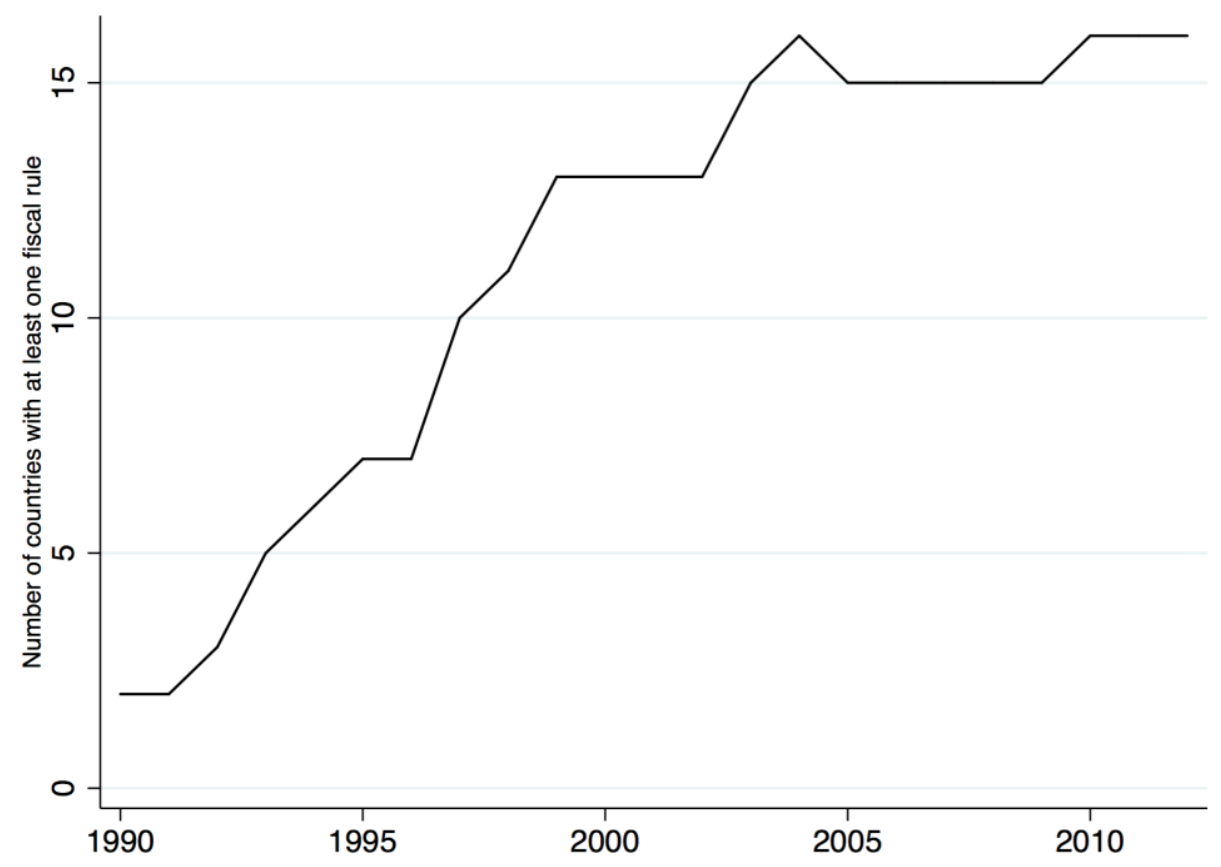

Figure 2. Fiscal Rule Strength Index in the EU (2012)

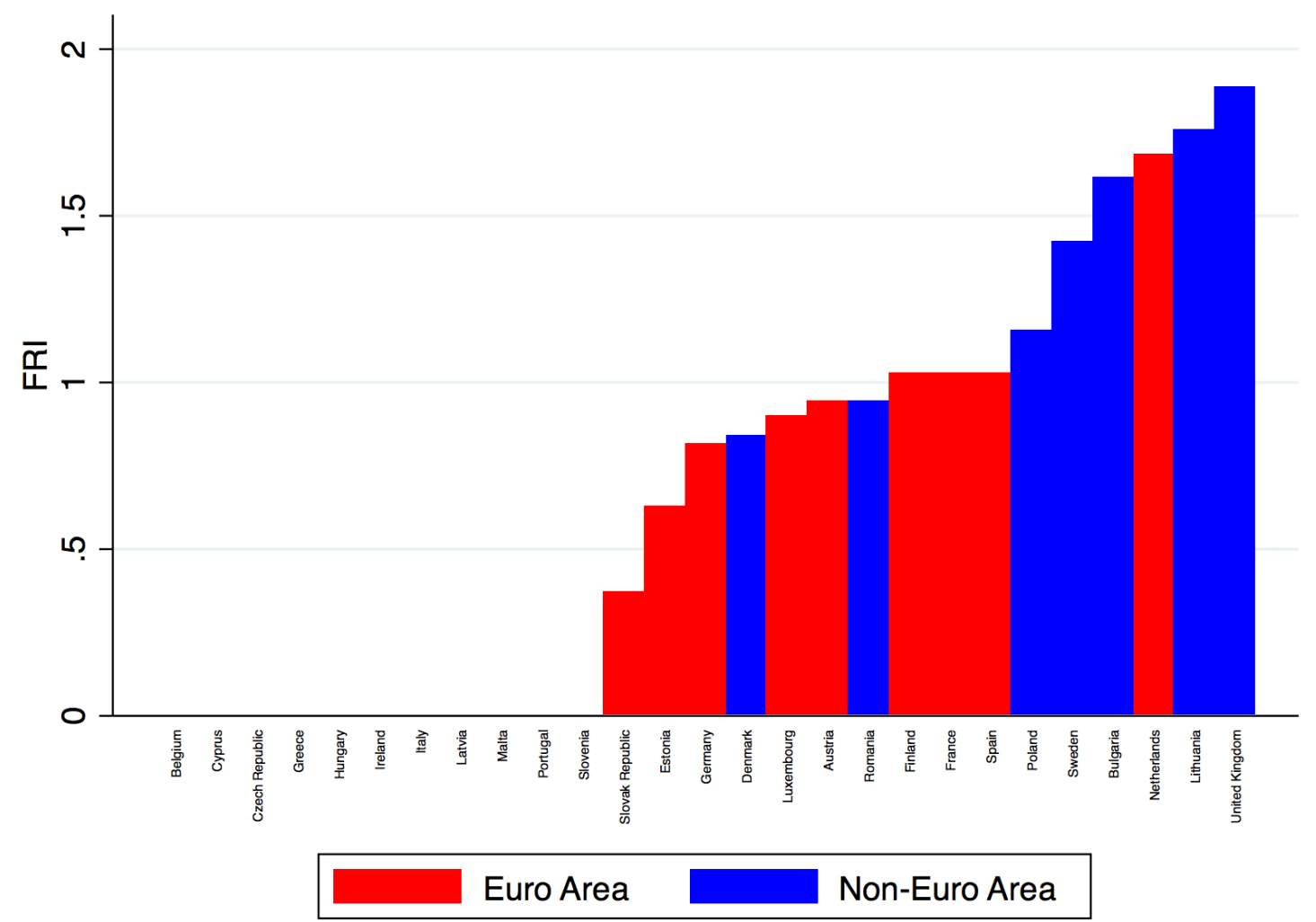


Figure 3. Fiscal Rule Strength Index 1990-2012 in EU, Euro Area and Selected Countries
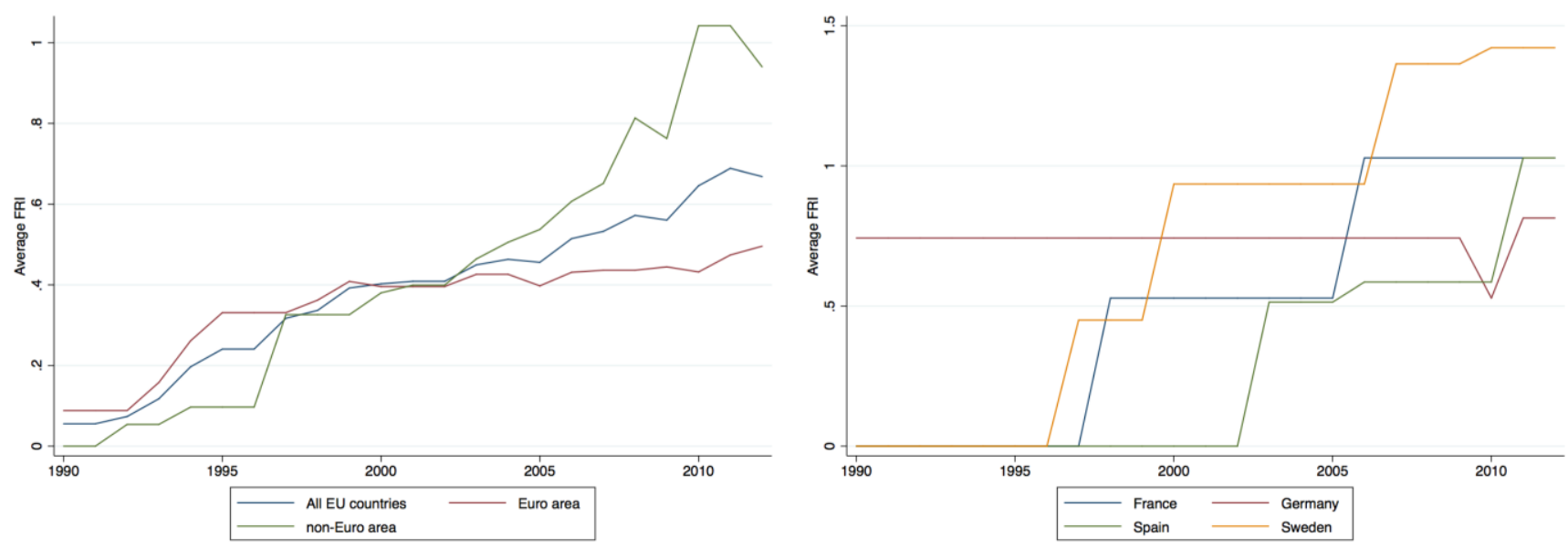

Figure 4. Marginal effects of fiscal rules on cyclically-adjusted primary balance at different levels of government efficiency

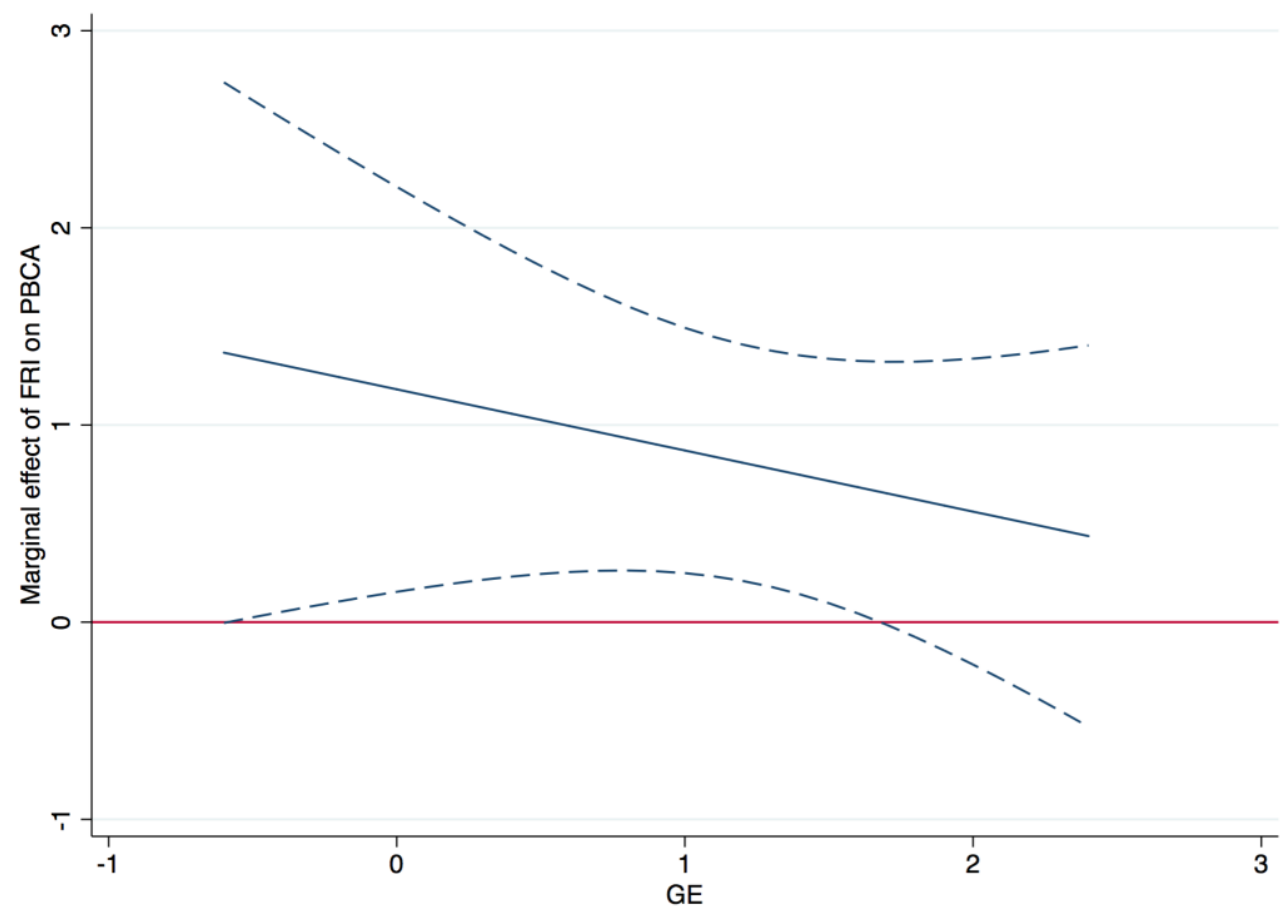

Note: $95 \%$ confidence bands (dashed lines) computed using the Delta method. 
Figure 5. Marginal effects of specific fiscal rules on cyclically-adjusted primary balance at different levels of government efficiency
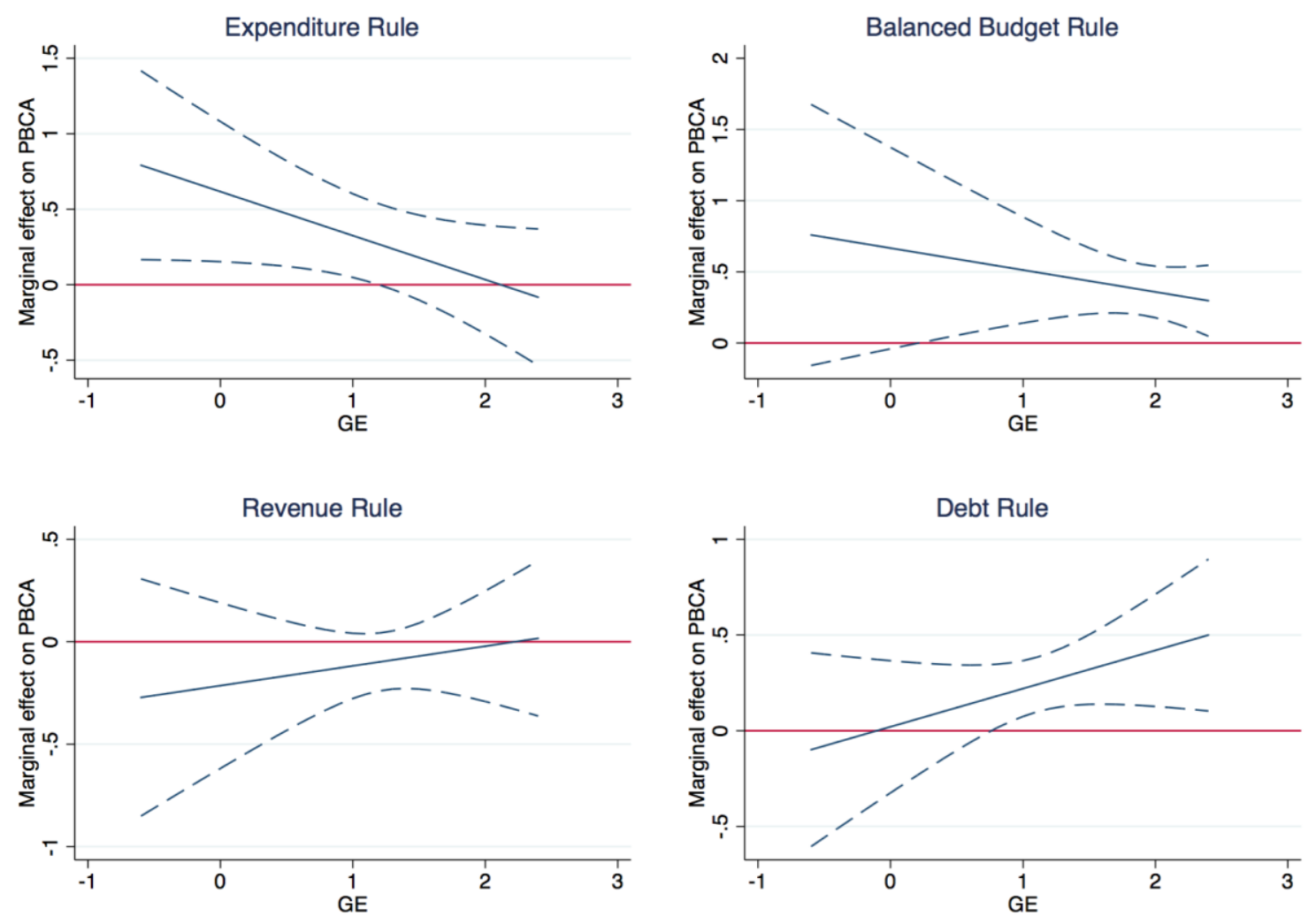

Note: $95 \%$ confidence bands (dashed lines) computed using the Delta method. 
Figure 6. Marginal effects of combinations of specific fiscal rules on cyclically-adjusted primary balance at different levels of government efficiency.
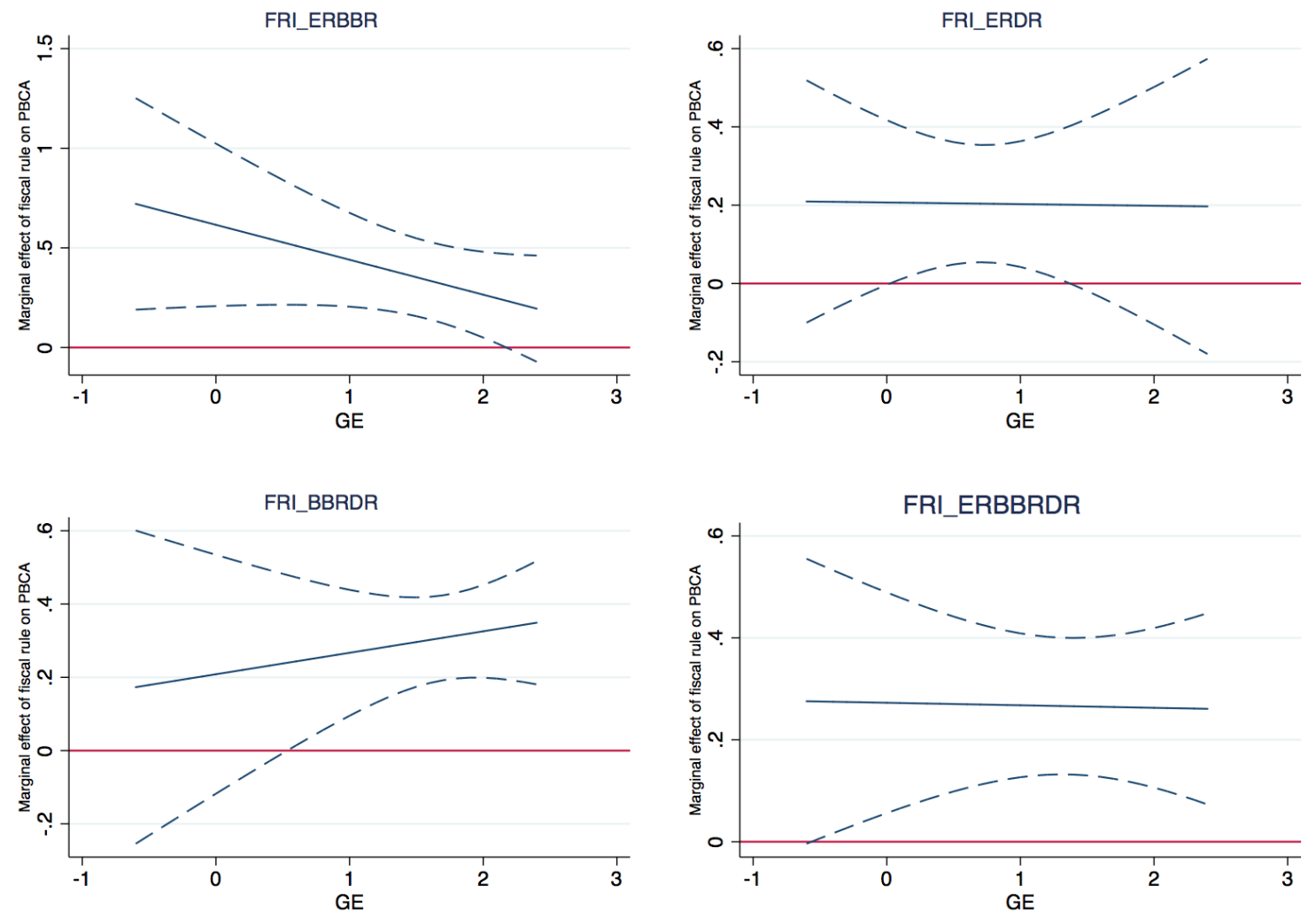

Note: $95 \%$ confidence bands (dashed lines) computed using the Delta method. 
Figure 7. Robustness tests: Marginal effects of alternative estimation methods.
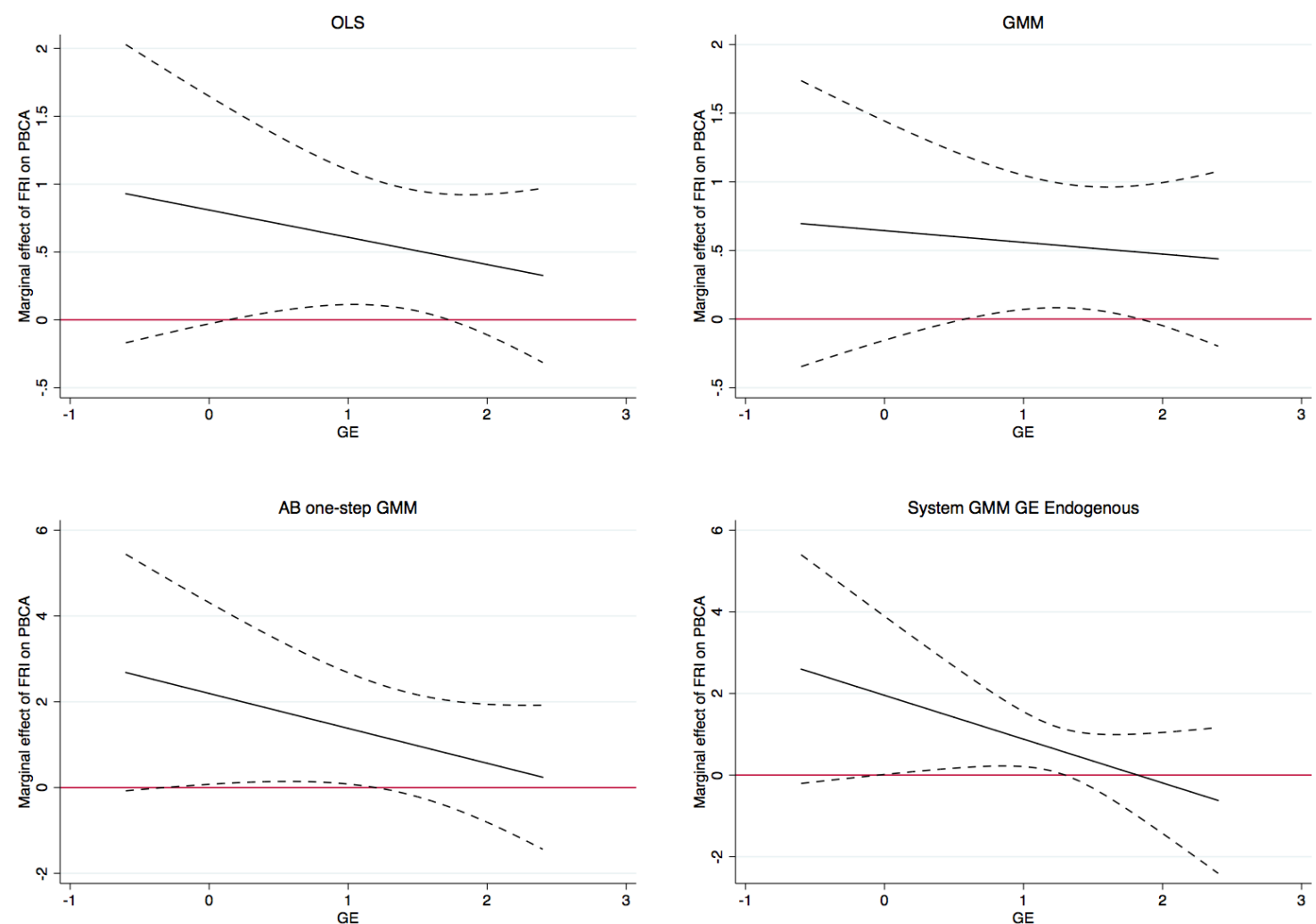

Note: Figure corresponds to estimation results reported in Table 7. 95\% confidence bands (dashed lines) computed using the Delta method. 
Figure 8. Robustness tests: Marginal effects of fiscal rules associated with alternative measures of government effectiveness (efficiency, transparency and commitment).
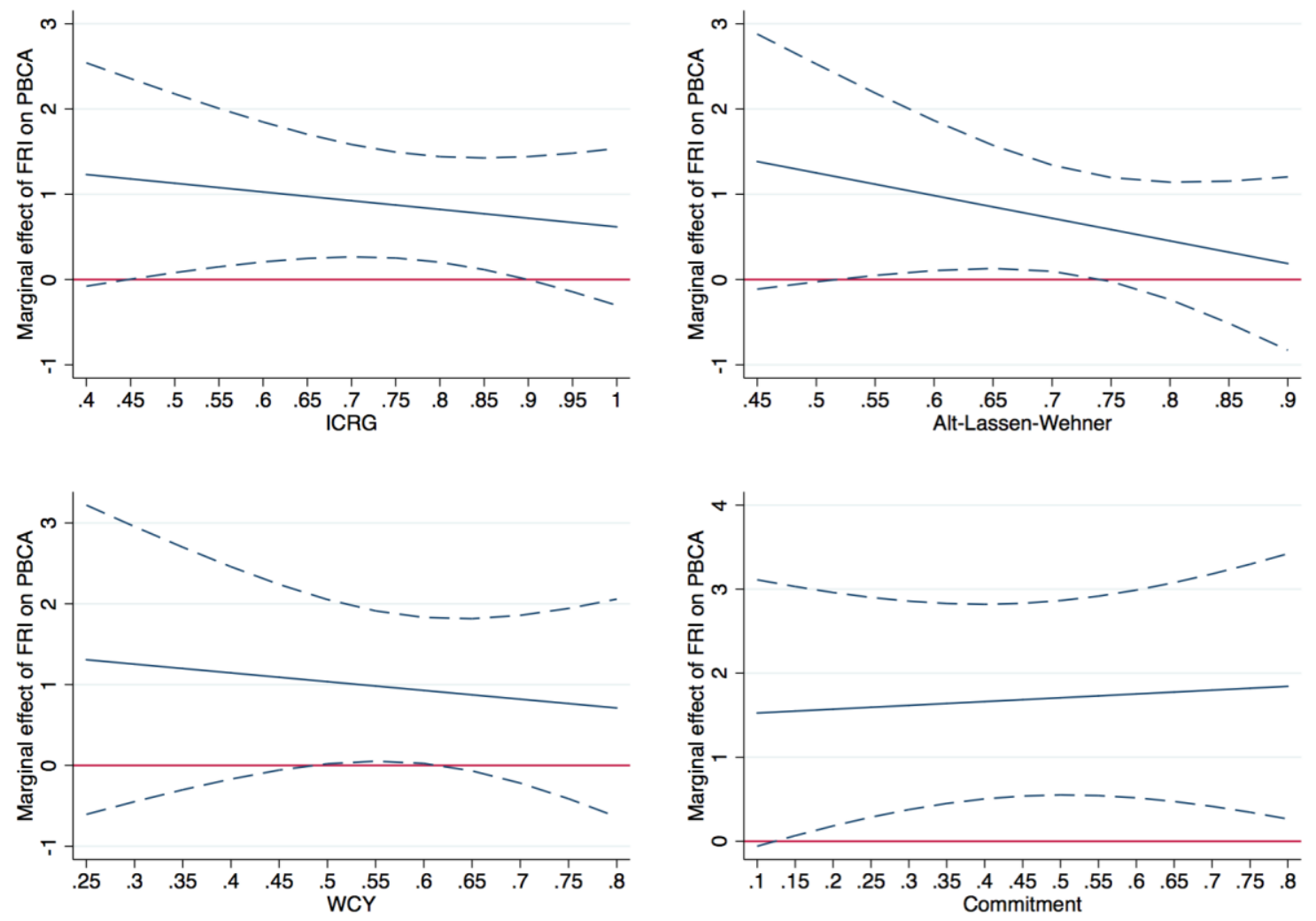

Note: $95 \%$ confidence bands (dashed lines) computed using the Delta method. 
Table A1: Point estimates of control variables in Table 2

\begin{tabular}{|c|c|c|}
\hline & (1) & (2) \\
\hline \multirow[t]{2}{*}{$\operatorname{PBCA}(-1)$} & $0.724 * * *$ & $0.718 * * *$ \\
\hline & $(0.085)$ & $(0.087)$ \\
\hline \multirow[t]{2}{*}{ GAP(-1) } & $-0.075 * * *$ & $-0.079 * * *$ \\
\hline & $(0.024)$ & $(0.026)$ \\
\hline \multirow[t]{2}{*}{$\operatorname{Debt}(-1)$} & $0.021 * * *$ & $0.021 * * *$ \\
\hline & $(0.004)$ & $(0.004)$ \\
\hline \multirow[t]{2}{*}{ Dependency } & 0.025 & 0.029 \\
\hline & $(0.023)$ & $(0.028)$ \\
\hline \multirow[t]{2}{*}{ Openness } & -0.007 & -0.120 \\
\hline & $(0.283)$ & $(0.308)$ \\
\hline \multirow[t]{2}{*}{ Population } & $-0.188^{*}$ & $-0.215^{*}$ \\
\hline & $(0.099)$ & $(0.107)$ \\
\hline \multirow[t]{2}{*}{ Inflation } & 0.032 & 0.048 \\
\hline & $(0.030)$ & $(0.040)$ \\
\hline \multirow[t]{2}{*}{ Years in office } & $0.173^{* *}$ & $0.174 * *$ \\
\hline & $(0.079)$ & $(0.082)$ \\
\hline \multirow[t]{2}{*}{ Election } & -0.356 & -0.352 \\
\hline & $(0.236)$ & $(0.243)$ \\
\hline \multirow[t]{2}{*}{ Plurality } & 0.030 & 0.083 \\
\hline & $(0.209)$ & $(0.202)$ \\
\hline \multirow[t]{2}{*}{ Gov. fragmentation } & 0.130 & 0.306 \\
\hline & $(0.506)$ & $(0.545)$ \\
\hline \multirow[t]{2}{*}{ Commitment } & -0.052 & 0.102 \\
\hline & $(0.292)$ & $(0.273)$ \\
\hline \multirow[t]{2}{*}{ Delegation } & $-0.582 * *$ & $-0.569^{*}$ \\
\hline & $(0.282)$ & $(0.279)$ \\
\hline \multirow[t]{2}{*}{ Run-up } & 0.384 & 0.316 \\
\hline & $(0.239)$ & $(0.232)$ \\
\hline \multirow[t]{2}{*}{ Enlarge } & 0.075 & 0.153 \\
\hline & $(0.269)$ & $(0.279)$ \\
\hline
\end{tabular}

Note: See notes to Table $\overline{4 .}$ 
Table A2: Robustness tests: Interaction of fiscal rules with commitment, delegation, EU membership and Euro Area membership.

\begin{tabular}{llllcl}
\hline \hline & ICRG & $\begin{array}{l}\text { Alt- } \\
\text { Lassen- } \\
\text { Wehner }\end{array}$ & WCY & $\begin{array}{c}\text { EuroArea } \\
\text { Commitment Member }\end{array}$ \\
\hline Z & 2.545 & 3.185 & 0.315 & 0.068 & -0.549 \\
FRI & $(1.523)$ & $(2.106)$ & $(2.881)$ & $(1.681)$ & $(0.380)$ \\
& 1.641 & 2.579 & 1.579 & 1.481 & $0.737 * *$ \\
FRI*Z & $(1.255)$ & $(1.840)$ & $(1.553)$ & $(0.926)$ & $(0.329)$ \\
& -1.023 & -2.657 & -1.085 & 0.454 & 0.247 \\
\hline \#countries & 27 & 25 & 24 & $(1.588)$ & $(0.391)$ \\
\#instruments & 21 & 22 & 24 & 24 & 27 \\
Obs & $(1.565)$ & $(2.479)$ & $(2.492)$ & 24 & 21 \\
AR(1) & 0.001 & 0.017 & 0.095 & 0.096 & 0.013 \\
AR(2) & 0.268 & 0.360 & 0.527 & 0.551 & 0.328 \\
Hansen & 0.270 & 0.476 & 0.240 & 0.448 & 0.445 \\
\hline
\end{tabular}

Note: $\mathrm{Z}$ denotes the variable shown in the first row of each column. Dependent variables are the cyclically-adjusted primary balance (percentage of GDP). FRI (GE) is the fiscal rules (government efficiency). A constant and all control variables are also included in the regressions but not shown here for brevity. $\operatorname{AR}(1)$ and $\operatorname{AR}(2)$ are tests of autocorrelation of the first and second order, respectively. Only p-values are reported for the Hansen J over-identifying tests and the two tests for autocorrelation. Clustered and robust standard errors reported below each estimate. $* * *$ denotes significant at the $1 \%$ level, $* *$ at the $5 \%$ level and $*$ at the $10 \%$ level. 